\title{
‡USGS
}

science for a changing world

\section{U.S. Geological Survey Science for the Wyoming Landscape Conservation Initiative-2016 Annual Report}

Open-File Report 2018-1048

U.S. Department of the Interior U.S. Geological Survey 
Front cover. The Little Mountain ecosystem, southwestern Wyoming. Photograph by Tim Assal, U.S. Geological Survey.

Back cover. Hydrologists from the U.S. Geological Survey Wyoming-Montana Water Science Center measure groundwater during winter months to determine contribution to streamflow. Photograph by Jerrod Wheeler, U.S. Geological Survey. 


\section{U.S. Geological Survey Science for the Wyoming Landscape Conservation Initiative-2016 Annual Report}

By Zachary H. Bowen, Ellen Aikens, Cameron L. Aldridge, Patrick J. Anderson, Timothy J. Assal, Anna D. Chalfoun, Geneva W. Chong, Cheryl A. Eddy-Miller, Steven L. Garman, Stephen S. Germaine, Collin G. Homer, Aaron Johnston, Matthew J. Kauffman, Daniel J. Manier, Cynthia P. Melcher, Kirk A. Miller, Annika W. Walters, Jerrod D. Wheeler, Daniel Wieferich, Anna B. Wilson, Teal B. Wyckoff, and Linda C.

Zeigenfuss

Open-File Report 2018-1048

U.S. Department of the Interior U.S. Geological Survey 


\section{U.S. Department of the Interior \\ RYAN K. ZINKE, Secretary}

\section{U.S. Geological Survey \\ William H. Werkheiser, Acting Director \\ exercising the authority of the Director}

U.S. Geological Survey, Reston, Virginia: 2018

For more information on the USGS—-the Federal source for science about the Earth, its natural and living resources, natural hazards, and the environment-visit https://www.usgs.gov or call 1-888-ASK-USGS (1-888-275-8747).

For an overview of USGS information products, including maps, imagery, and publications, visit https://store.usgs.gov.

Any use of trade, firm, or product names is for descriptive purposes only and does not imply endorsement by the U.S. Government.

Although this information product, for the most part, is in the public domain, it also may contain copyrighted materials as noted in the text. Permission to reproduce copyrighted items must be secured from the copyright owner.

Suggested citation:

Bowen, Z.H., Aikens, E., Aldridge, C.L., Anderson, P.J., Assal, T.J., Chalfoun, A.D., Chong, G.W., EddyMiller, C.A., Garman, S.L., Germaine, S.S., Homer, C.G., Johnston, A., Kauffman, M.J., Manier, D.J., Melcher, C.P., Miller, K.A., Walters, A.W., Wheeler, J.D., Wieferich, D., Wilson, A.B., Wyckoff, T.B., and Zeigenfuss, L.C., 2018, U.S. Geological Survey science for the Wyoming Landscape Conservation Initiative-2016 annual report: U.S. Geological Survey Open-File Report 2018-1048, 49 p., https://doi.org/10.3133/ofr20181048.

ISSN 2331-1258 (online) 


\section{Contents}

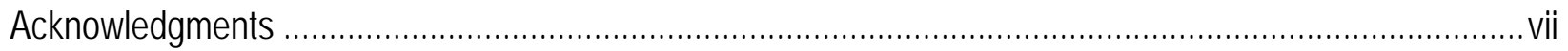

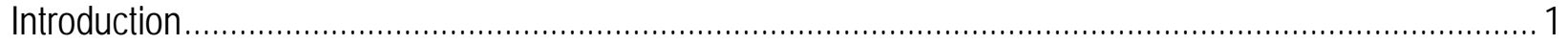

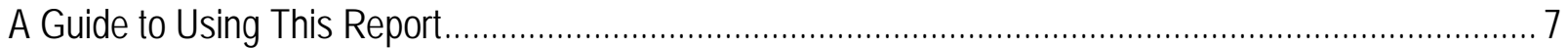

Highlights of FY2016 USGS WLCI Science Accomplishments.......................................................... 13

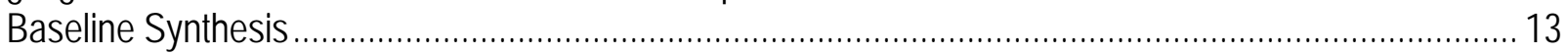

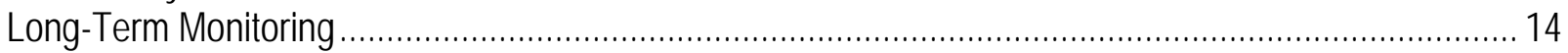

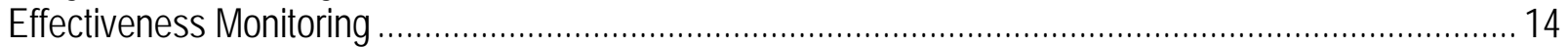

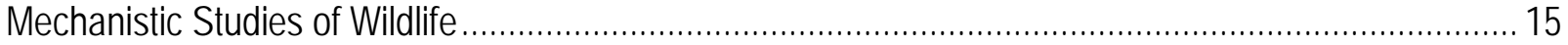

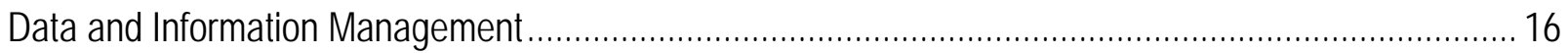

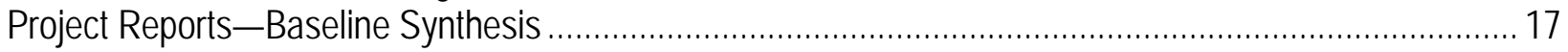

Application of Comprehensive Assessment to Support Decision Making and Conservation Actions ....... 17

Wind Energy and Wild life in Southwest Wyoming ....................................................................... 18

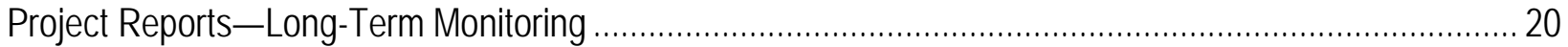

Framework and Indicators for Long-Term Monitoring................................................................ 20

Time-Series Analysis of Multiresolution Imagery to Quantify Sagebrush Defoliation and Mortality in

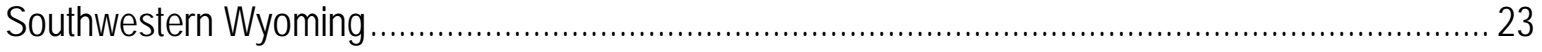

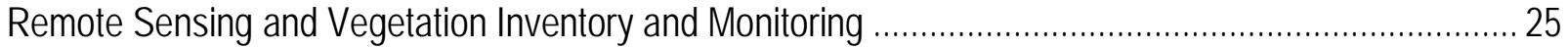

Long-Term Monitoring of Surface Water, Groundwater, and Water Quality ......................................... 27

Evaluation of Groundwater Interaction with Small Streams in the Western Green River Basin to Enhance

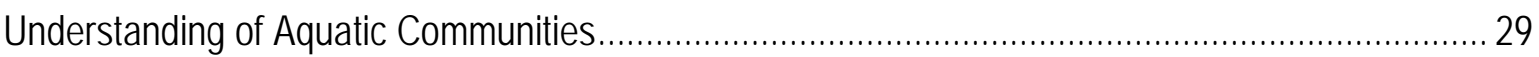

Synoptic Streamflow Measurements on the New Fork and Green Rivers.......................................... 30

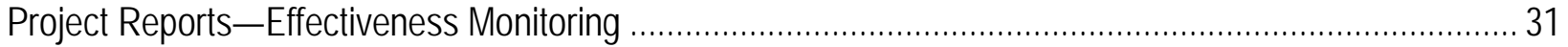

Plant Phenology Metrics to Evaluate Sagebrush in the WLCI Region................................................. 31

Mapping Mixed Mountain Shrub Communities to Support WLCl Conservation Planning and Effectiveness

Monitoring of Habitat Treatments....................................................................................... 33

Landscape Assessment and Monitoring of Semiarid Woodlands in the Little Mountain Ecosystem ......... 34

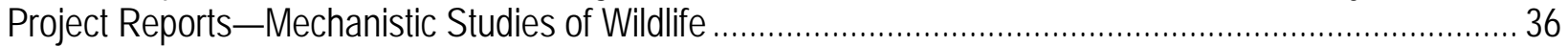

Modeling Habitat Associations and Distribution of Pygmy Rabbits...................................................... 36

Modeling Greater Sage Grouse Population Responses to Landscape Changes .................................... 37

Mechanistic Understanding of Energy Resource Development Effects on Songbirds............................ 39

Identifying Threshold Levels of Development that Impede Wyoming Mule Deer Migrations ..................... 41

Drivers of Native Fish Community Response to Oil and Gas Development .......................................... 43

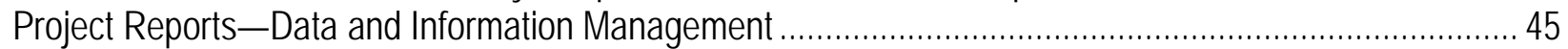

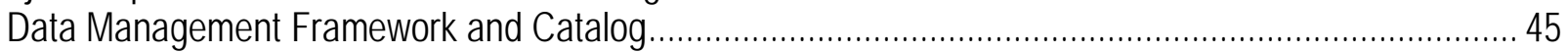

References Cited and FY2016 WLCI Publications ............................................................................. 46

\section{Figures}

1. The boundary and major features of the Wyoming Landscape Conservation Initiative region.............2

2. Sagebrush Recovery Index in southwest Wyoming related to years after attenuation of drilling

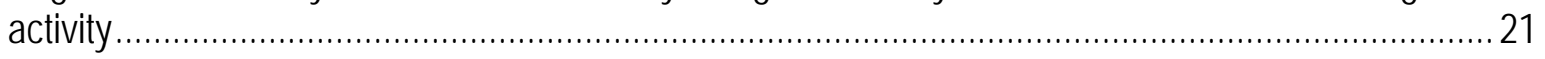

3. Cumulative net anomalies of sagebrush ecosystem productivity for the 2014 growing season ..........24

4. Locations of U.S. Geological Survey field-based study areas associated with long-term monitoring projects during fiscal year 2016 in the Wyoming Landscape Conservation Initiative region ..............27 
5. Use of vegetation by mule deer in western Wyoming relative to date of peak green-up during 2013 and 2014 mule deer migration season.

6. Trends in forest condition over the full time period of study for locations within the Little Mountain Ecosystem

7. The estimated mean with 95 percent confidence intervals of the slope of linear regression between the date of deer use at a given location and the date of peak instantaneous rate of green-up at the same location for individual deer movements in each year in the energy study area

\section{Tables}

1. Major management needs and objectives identified by partners of the Wyoming Landscape Conservation Initiative during workshops and meetings prior to initiative implementation...

2. Summary of U.S. Geological Survey science and technical development projects conducted in fiscal year 2016 for the Wyoming Landscape Conservation Initiative

3. Products published in fiscal year 2016 related to work on long-term monitoring of surface water, groundwater, and water quality in the Wyoming Landscape Conservation Initiative region 


\section{Conversion Factors}

U.S. customary units to International System of Units

\begin{tabular}{|c|c|c|}
\hline Multiply & By & To obtain \\
\hline \multicolumn{3}{|c|}{ Area } \\
\hline acre & 4,047 & square meter $\left(\mathrm{m}^{2}\right)$ \\
\hline acre & 0.004047 & square kilometer $\left(\mathrm{km}^{2}\right)$ \\
\hline
\end{tabular}

International System of Units to U.S. customary units

\begin{tabular}{|c|c|c|}
\hline Multiply & By & To obtain \\
\hline \multicolumn{3}{|c|}{ Length } \\
\hline meter (m) & 3.281 & foot $(\mathrm{ft})$ \\
\hline kilometer (km) & 0.6214 & mile (mi) \\
\hline meter (m) & 1.094 & yard (yd) \\
\hline centimeter & 0.3937 & inch (in.) \\
\hline
\end{tabular}

\section{Common and Scientific Species Names}

\begin{tabular}{|c|c|c|c|}
\hline \multicolumn{2}{|c|}{ Animal species } & \multicolumn{2}{|c|}{ Plant species } \\
\hline Common name & Scientific name & Common name & Scientific name \\
\hline Brewer's sparrow & Spizella breweri & Antelope bitterbrush & Purshia tridentata \\
\hline $\begin{array}{l}\text { Colorado River } \\
\text { cutthroat trout }\end{array}$ & $\begin{array}{l}\text { Oncorhynchus clarkii } \\
\quad \text { pleuriticus }\end{array}$ & Aspen & Populus tremuloides \\
\hline Deer mouse & Peromyscus maniculatus & Cheatgrass & Bromus tectorum \\
\hline Greater sage grouse & Centrocercus urophasianus & Chokecherry & Prunus virginiana \\
\hline Mountain sucker & Catostomus platyrhynchus & $\begin{array}{l}\text { Curl-leaf mountain- } \\
\text { mahogany }\end{array}$ & Cercocarpus ledifolius \\
\hline Mottled sculpin & Cottus bairdii & Mountain-mahogany & Cercocarpus montanus \\
\hline Mule deer & Odocoileus hemionus & Sagebrush species & Artemisia spp. \\
\hline Pronghorn & Antilocapra americana & Western serviceberry & Amelanchier alnifolia \\
\hline Pygmy rabbit & Brachylagus idahoensis & Willow species & Salix spp. \\
\hline Sage thrasher & Oreoscoptes montanus & & \\
\hline Sagebrush sparrow & Artemisiospiza nevadensis & & \\
\hline $\begin{array}{l}\text { Thirteen-lined ground } \\
\text { squirrel }\end{array}$ & Ictidomys tridecemlineatus & & \\
\hline Uinta ground squirrel & Urocitellus armatus & & \\
\hline
\end{tabular}




\section{Abbreviations}

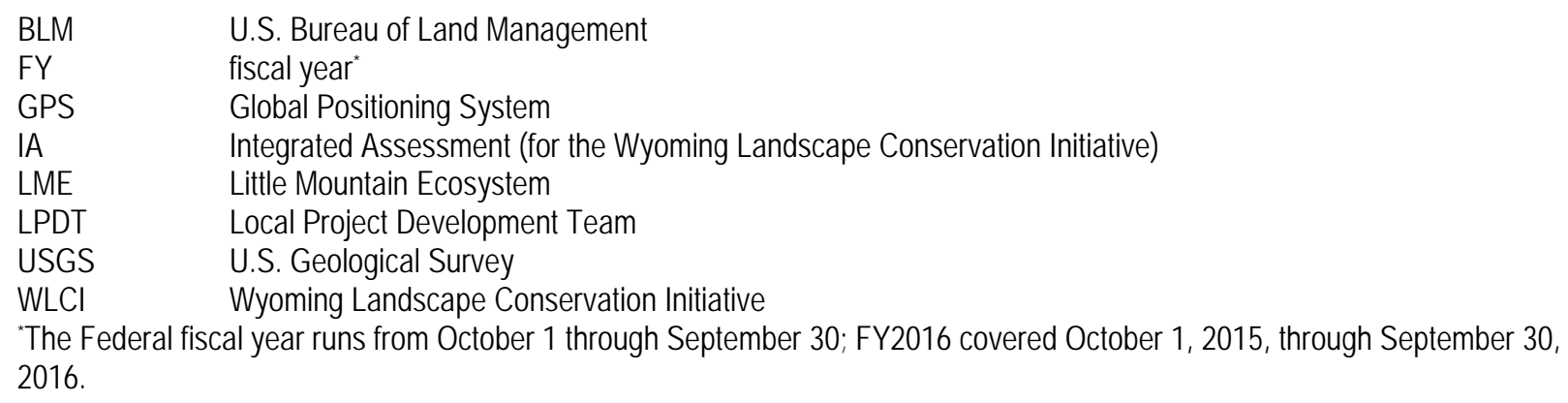

\section{Contributing Authors}

\section{Ellen Aikens}

Wyoming Cooperative Fish and Wildlife Research Unit, Department of Zoology and Physiology, University of Wyoming, Laramie, Wyo.

\section{Cameron L. Aldridge}

U.S. Geological Survey, Fort Collins Science Center Cooperator, Colorado State University, Natural Resource Ecology Laboratory, Fort Collins, Colo.

Patrick J. Anderson

U.S. Geological Survey, Fort Collins Science Center, Fort Collins, Colo.

Timothy J. Assal

U.S. Geological Survey, Fort Collins Science Center, Fort Collins, Colo.

Zachary H. Bowen

U.S. Geological Survey, Fort Collins Science Center, Fort Collins, Colo.

Anna D. Chalfoun

U.S. Geological Survey, Wyoming Cooperative Fish and Wildlife Research Unit, Department of Zoology and Physiology, University of Wyoming, Laramie, Wyo.

Geneva W. Chong

U.S. Geological Survey, Northern Rocky Mountain Science Center, Jackson, Wyo.

Cheryl A. Eddy-Miller

U.S. Geological Survey, Wyoming-Montana Water Science Center, Cheyenne, Wyo.

Steven L. Garman

Bureau of Land Management, National Operations Center, Denver, Colo.

Stephen S. Germaine

U.S. Geological Survey, Fort Collins Science Center, Fort Collins, Colo.

Collin G. Homer

U.S. Geological Survey, Earth Resources Observation and Science Center, Sioux Falls, S. Dak. 
Aaron Johnston

U.S. Geological Survey, Northern Rocky Mountains Science Center, Bozeman, Mont.

Matthew J. Kauffman

U.S. Geological Survey, Wyoming Cooperative Fish and Wildlife Research Unit, Department of Zoology and Physiology, University of Wyoming, Laramie, Wyo.

Daniel J. Manier

U.S. Geological Survey, Fort Collins Science Center, Fort Collins, Colo.

Cynthia P. Melcher

U.S. Geological Survey, Fort Collins Science Center, Fort Collins, Colo.

Kirk A. Miller

U.S. Geological Survey, Wyoming-Montana Water Science Center, Cheyenne, Wyo.

Annika W. Walters

U.S. Geological Survey, Wyoming Cooperative Fish and Wildlife Research Unit, Department of Zoology and Physiology, University of Wyoming, Laramie, Wyo.

Jerrod D. Wheeler

U.S. Geological Survey, Wyoming-Montana Water Science Center, Cheyenne, Wyo.

Daniel Wieferich

U.S. Geological Survey, Core Science Analytics, Synthesis, and Libraries, Denver, Colo.

Anna B. Wilson

U.S. Geological Survey, Central Mineral and Environmental Resources Science Center, Denver, Colo.

Teal B. Wyckoff

Wyoming Cooperative Fish and Wildlife Research Unit, Department of Zoology and Physiology, University of Wyoming, Laramie, Wyo.

Linda C. Zeigenfuss

U.S. Geological Survey, Fort Collins Science Center, Fort Collins, Colo.

\section{Acknowledgments}

The authors thank the Wyoming Landscape Conservation Initiative (WLCI) Science and Technical Advisory Committee and the Coordination Team for their ideas and advice regarding this report, and the authors acknowledge the Wyoming Game and Fish Department and the U.S. Bureau of Land Management for supporting the U.S. Geological Survey's WLCl efforts by providing data and other information. The authors also wish to thank Mark Vandever and Sara Oyler-McCance, both U.S. Geological Survey, for their thorough reviews. 


\section{U.S. Geological Survey Science for the Wyoming Landscape Conservation Initiative-2016 Annual Report}

By Zachary H. Bowen, Ellen Aikens, Cameron L. Aldridge, Patrick J. Anderson, Timothy J. Assal, Anna D. Chalfoun, Geneva W. Chong, Cheryl A. Eddy-Miller, Steven L. Garman, Stephen S. Germaine, Collin G. Homer, Aaron Johnston, Matthew J. Kauffman, Daniel J. Manier, Cynthia P. Melcher, Kirk A. Miller, Annika W. Walters, Jerrod D. Wheeler, Daniel Wieferich, Anna B. Wilson, Teal B. Wyckoff, and Linda C. Zeigenfuss

\section{Introduction}

Southwestern Wyoming is a landscape of wide-open spaces abounding with natural resources, such as wildlife, rangelands, and water. These characteristics are the basis of important recreation, ranching, and farming economies that form much of the rich cultural history and socioeconomic fabric of its communities. Also counted among the region's abundant natural resources are a wealth of energy resources, including oil, gas, coal, wind, and solar, and mineral resources, such as trona, uranium, and phosphate. Since the early 2000s, energy development has been rapidly expanding in this region. New technologies for extracting unconventional oil and gas and tapping renewable resources, particularly wind, are helping to meet our Nation's increasing energy demands and contribute to the local economy. Growth in energy development has fueled an accompanying increase in human population and associated development across the region.

As all forms of development increase in southwestern Wyoming, concerns about potential negative effects on the region's wildlife populations and habitats, water and air resources, agriculture- and recreation-based economies, and quality of life have intensified. In 2007, to address these concerns, the Wyoming Landscape Conservation Initiative (WLCI) was established by the U.S. Geological Survey (USGS) and public agencies with jurisdiction over land and (or) natural resources in southwestern Wyoming (fig. 1) (D’Erchia, 2016). The WLCI partner agencies outlined the initiative's mission, objectives, organization, and partner roles (see https://www.wlci.gov/partners and https://www.wlci.gov/content/management-documents for more information).

\section{Mission Statement of the Wyoming Landscape Conservation Initiative}

Implement a long-term, science-based program to assess and enhance the quality and quantity of aquatic and terrestrial habitats at a landscape scale in southwest Wyoming while facilitating responsible development through local collaboration and partnerships. 


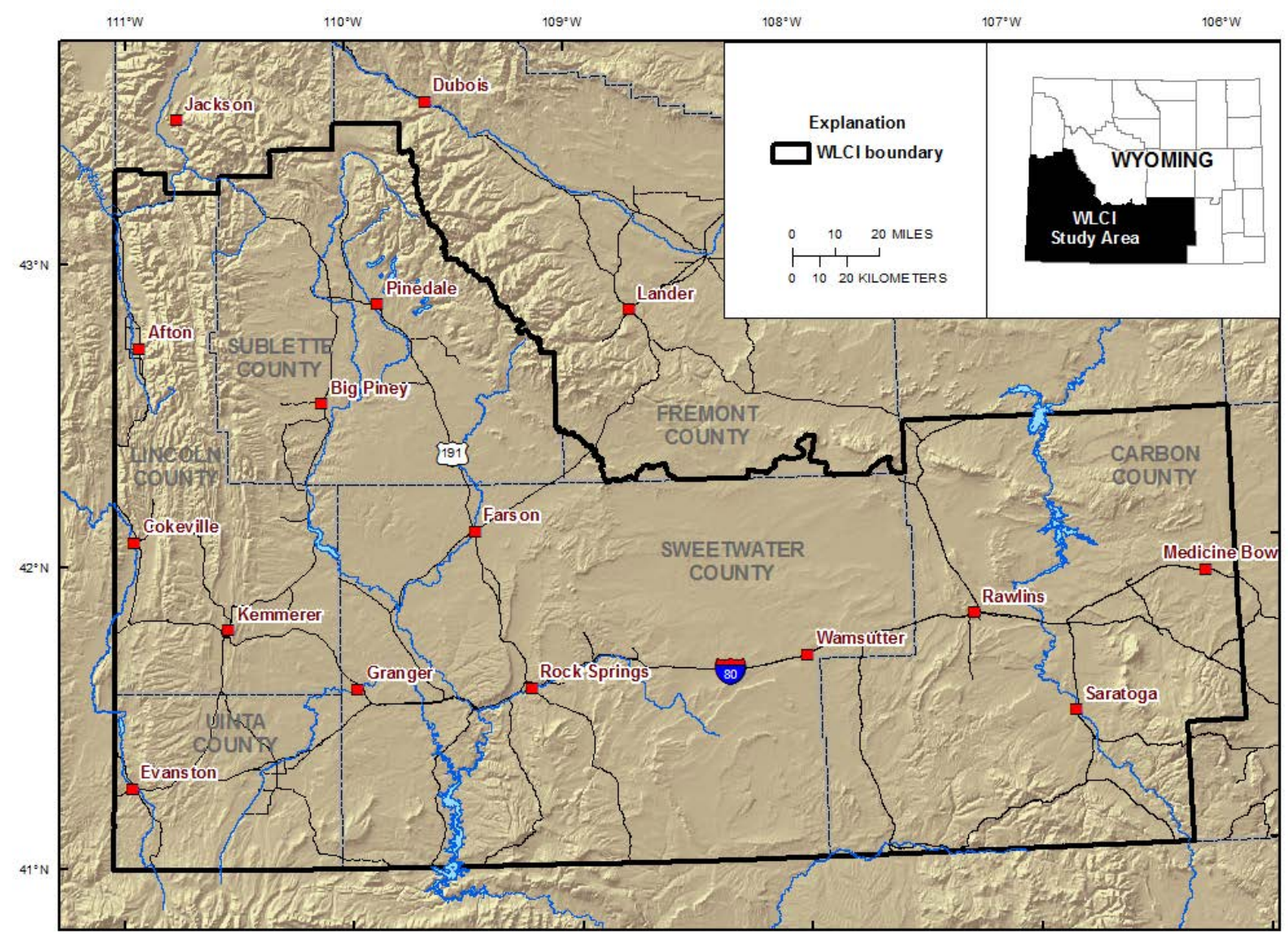

Figure 1. The boundary and major features of the Wyoming Landscape Conservation Initiative (WLCl) region.

Early on, a series of scoping meetings and workshops were held to identify potential WLCI partners and the major management needs and objectives for the WLCI region, focal habitats, and wildlife Species of Greatest Conservation Need (Wyoming Game and Fish Department, 2010) that would be central to WLCI-funded activities. The six management needs and objectives (table 1) (D’Erchia, 2008) fell into four broad themes, listed below.

- Identify and assess the cumulative environmental effects (current and future) associated with energy resource development and other major drivers of landscape change.

- Develop methods for efficient, effective monitoring of ecosystem conditions across a vast and heterogeneous landscape.

- Evaluate the efficacy of habitat enhancement and restoration projects in meeting objectives.

- Develop the tools for housing, displaying, and disseminating data and other information to support planning and decision making for conserving ecosystem function and integrity in the WLCI region. 
Table 1. Major management needs and objectives identified by partners of the Wyoming Landscape Conservation Initiative (WLCl) during workshops and meetings prior to initiative implementation.

\section{Management need Objectives}

1. Identify key drivers A. Identify, quantify, and prioritize key drivers of change, including interactive drivers and those measured inadequately in the past, of change

such as energy-development footprints over time (including initial surficial disturbance and associated short- and long-term disturbances, fire, invasive species, and livestock grazing).

B. Develop new methods or improve/refine existing models for predicting potential changes in key drivers over time and projecting likely future responses to them.

C. Improve predictive capabilities of future-scenario models, and update scientific understanding of the origin/occurrence of energy/mineral resources based on most current information for viable deposit types/assessment units.

D. Develop methods to assess full costs (exploration, extraction, use) of energy/mineral development.

2. Identify condition A. Identify key aquatic/terrestrial species or assemblages (including indicator, umbrella, socially/economically important, or special and distribution of key wildlife species/habitats, and identify species habitat status species).

B. Assess baseline conditions and determine landscape-level habitat requirements for important aquatic/terrestrial species (special status, keystone, or economically/socially important).

C. Use Wyoming Game and Fish Department’s Strategic Habitat Plan as a foundation to delineate spatiotemporal habitat distribution and to map key/high-quality habitats for key species/assemblages.

requirements $\quad$ D. Identify key areas of conservation concern/priority by mapping important, sensitive, and rare habitats and critical habitats (including nesting, rearing, wintering, spawning, and migration) required for long-term persistence of key wildlife species.

E. Identify vulnerability/sensitivity of key habitats/areas to key drivers of change.

F. Relate habitat characteristics to animal distribution/population dynamics (an index of habitat quality) to assess effects of key drivers of change on aquatic/terrestrial wildlife/habitats.

3. Evaluate wildlife A. Evaluate direct effects of energy development and other major drivers on physiology/demographic performance of wildlife and livestock (individual species and species groups) and livestock.

responses to $\quad$ B. Evaluate indirect effects of habitat alteration on wildlife/livestock from invasive nonnative plants, altered disturbance regimes, development increased susceptibility to disease, altered social dynamics, or other changes.

C. Assess different patch-size needs/edge effects that influence wildlife behavior and population structure/growth.

D. Develop methods to assess influence of energy development on livestock-management systems.

\footnotetext{
4. Evaluate the effectiveness of

A. Evaluate effectiveness of specific habitat improvement/restoration practices in different habitat types/precipitation zones.

restoration,

B. Evaluate/guide refinement of Best Management Practices.

reclamation, and

C. Evaluate relations between observed resource responses and management activities (restoration, reclamation, and habitat-

mitigation activities improvement projects).

D. Design a framework for objectively developing the most effective restoration/enhancement projects on a landscape scale.
} 
Table 1. Major management needs and objectives identified by partners of the Wyoming Landscape Conservation Initiative (WLCl) during workshops and meetings prior to initiative implementation.-Continued

\section{Management need}

5. Develop an integrated inventory and monitoring strategy

\section{Objectives}

A. Develop inventory/monitoring approach designed to evaluate overall effectiveness of the WLCI (on-the-ground habitat projects) and support assessment of cumulative effects.

B. Coordinate with WLCI partners to establish landscape-scale monitoring strategies/protocols.

C. Integrate WLCI inventory/monitoring programs with other local, State, and Federal efforts.

D. Make inventory/monitoring information accessible to WLCI partners/resource managers through data-management framework/data clearinghouse.

E. Integrate inventory/monitoring efforts into an adaptive management framework.
6. Develop a data clearinghouse and
A. Develop a web-based WLCI data clearinghouse that can protect confidential, sensitive, and (or) proprietary information.
information
A. Develop a web-based WLCI data clearinghouse that can protect confidential, sensitive, and (or) proprietary information.
B. Develop/implement a project tracking/database system to provide summaries of habitat projects and associated spatial data.
C. Provide data-management, visualization (mapping), and decision-support tools for the WLCI.
management
D. Provide public information/outreach on WLCI habitat improvement/science activities. 
Short- and long-term science activities for addressing each WLCI management objective were identified through a collaborative effort between the USGS and other WLCI partners (Bowen and others, 2009b). The USGS represents the science and technical support arm of the WLCI effort. The USGS WLCI Science Team (hereafter Science Team) is responsible for building the scientifically defensible foundation of knowledge on which WLCI planners, decision makers, and resource managers may base their WLCI activities. The direction of USGS science is evaluated annually and further refined or adjusted as needed through meetings with the WLCI Science and Technical Advisory Committee and the USGS WLCI Steering Committee. Local Project Development Teams (LPDTs) in the WLCI identify science needs and priorities and share this information directly with USGS. The teams also meet to identify WLCI habitat enhancement and restoration priorities for the following year. Although the USGS does not conduct habitat enhancement projects, the Science Team tailors its activities to monitor the effectiveness of these management actions. Overall, the iterative process of review and refinement helps ensure that USGS science remains highly relevant to WLCI partner needs, changing conditions, and the implications of emerging knowledge and technologies.

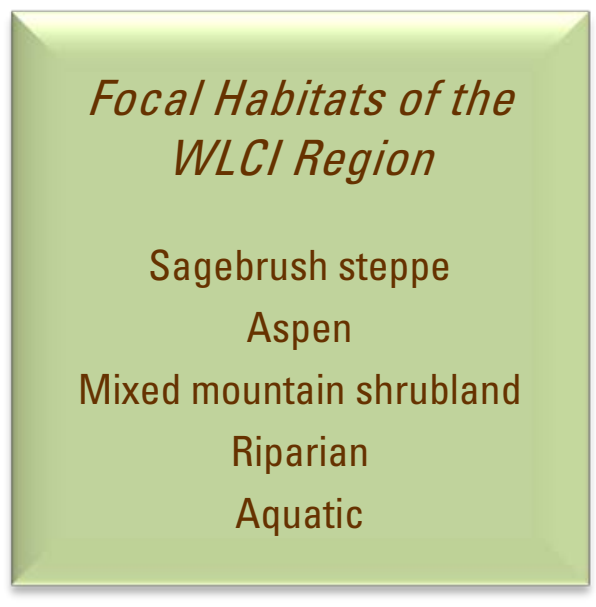




\section{Roles of the U.S. Geological Survey in the WLCI}

- The USGS Science Team-a multidisciplinary team of more than 25 scientists and technological experts - includes terrestrial and aquatic ecologists; energy and mineral geologists; hydrologists; socioeconomic scientists; geographers; and specialists in remote sensing, geographic information systems, and geospatial analysis.

o The Science Team performs scientific research and develops tools that inform and support WLCI partner planning, decision making, and on-theground management actions.

o Results of USGS science serve as building blocks for future science projects.

o The Science Team integrates the approaches and results of many disciplines to enhance the scope and depth of its assessments, monitoring activities, research capacities, and products.

- The USGS also provides a liaison to the WLCI Coordination Team to

o facilitate coordination, communication, and activities among WLCI partners;

o help WLCI partners integrate new information and technologies in their planning, decision making, and management actions; and

o facilitate the dissemination, interpretation, and use of USGS findings, products, and tools.

The USGS science strategy for the WLCI is based on a three-tiered approach for organizing and guiding USGS WLCI science and related activities. A detailed explanation of this structure can be found in previous annual reports (Bowen and others, 2009a, 2010, 2011, 2013, 2014a, b, 2015, 2016). The "ground-level" or "foundation" tier of our science strategy is a largescale, ongoing Baseline Synthesis. Science activities of this tier entail acquiring, compiling, standardizing, and integrating existing and new data for ascertaining baseline resource conditions, conducting landscape-scale assessments, and projecting potential trajectories of habitat conditions and wildlife populations under future scenarios of energy resource development and other changes. The Baseline Synthesis provides the foundation for our second tier, Targeted Monitoring and Research. The USGS Science Team has been highly successful in developing long-term, tiered research studies that fill basic data gaps and (or) incorporate technological advances to maximize the scope, resolution, and accuracy of information gained. From the information gained in these earlier studies, new questions (hypotheses) have emerged and are being tested to answer increasingly more specific questions about what drives changes on the landscape and how and why species respond to those changes. By using this classic systematic scientific method, the Science Team is laying a solid and highly defensible foundation for management and future science, both within the WLCI and beyond. The top tier of the USGS science strategy, Integration and Coordination, is managed by the USGS liaison to the WLCI 
Coordination Team by working closely with WLCI partners and leadership teams. The USGS provides ongoing technological support for all three tiers of USGS science activity.

\section{A Guide to Using This Report}

The USGS has produced a comprehensive annual report to highlight its WLCI science accomplishments for each Federal fiscal year (FY; October 1-September 30) since inception of the WLCI (Bowen and others, 2009a, 2010, 2011, 2013, 2014a, b, 2015, 2016). Past reports can be accessed at the web addresses listed in the box below. This open-file report is the ninth WLCI annual report and highlights USGS science and technical assistance activities conducted in FY2016. The FY2016 activities and their relations to WLCI management needs (table 1) and other WLCI activities are summarized in table 2.

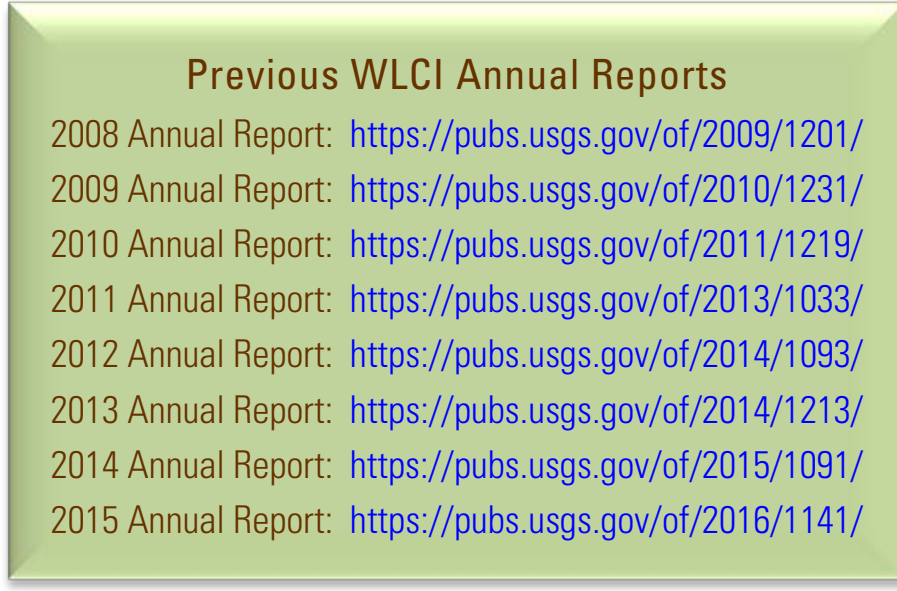

To help WLCI partners focus on accomplishments, products, take-home messages, and applications of USGS work, this report provides (1) an overview and highlights of FY2016 USGS WLCI Science Accomplishments (p. 13-16) and (2) individual one- to two-page reports for each FY2016 project, including snapshots of project needs and objectives, general approaches, recent findings, and major products (p. 17-45). Individual reports include in-depth information on each new project; in-depth information on ongoing and completed projects can be found in earlier annual reports. Individual reports also include, where applicable, web addresses to directly access USGS and outside products published in FY2016. For more information on USGS WLCI activity, including Coordination and Integration and Evaluations of USGS science, contact Patrick Anderson (970-226-9488; andersonpj@usgs.gov) and Zachary Bowen (970226-9218; bowenz@usgs.gov). 
Table 2. Summary of U.S. Geological Survey science and technical development projects conducted in fiscal year 2016 for the Wyoming Landscape Conservation Initiative (WLCl).

[For each project, the WLCI management needs and objectives addressed (directly or indirectly) by the project are listed by alphanumeric codes that correspond to management needs and associated objectives listed in table 1; for example, $1 \mathrm{~A}$ refers to management need 1 , objective A. The summary also includes project status as of September 30, 2016; focal species and (or) habitats addressed by the project; and intended or potential applications of project outcomes (such as products, databases, models, or web tools). For activities of particular interest, the project titles and page numbers have been hyperlinked to the project reports included later in this report. FY, fiscal year; no., number; N/A, not applicable]

\begin{tabular}{|c|c|c|c|c|c|}
\hline $\begin{array}{l}\text { Management needs } \\
\text { and objectives } \\
\text { addressed }\end{array}$ & Project title & $\begin{array}{l}\text { Status at } \\
\text { end of } \\
\text { FY2016 }\end{array}$ & $\begin{array}{l}\text { Focal species and (or) } \\
\text { habitat }^{1}\end{array}$ & $\begin{array}{l}\text { Intended and potential } \\
\text { applications of project outcomes }\end{array}$ & Page no. \\
\hline \multicolumn{6}{|c|}{ Baseline Synthesis } \\
\hline $\begin{array}{l}\text { 1A-C; 2A-F; 3A; } \\
\quad 5 \mathrm{D}\end{array}$ & $\begin{array}{l}\text { Application of Comprehensive Assessment } \\
\text { to support decision making and } \\
\text { conservation actions-integrated } \\
\text { assessment }\end{array}$ & Ongoing & $\begin{array}{l}\text { Any species and focal } \\
\text { habitat in WLCI study } \\
\text { area }\end{array}$ & $\begin{array}{l}\text { Status \& trends, science } \\
\text { foundation, policy/outreach }\end{array}$ & 17 \\
\hline $\begin{array}{l}1 \mathrm{~A}-\mathrm{C} ; 2 \mathrm{~A}-\mathrm{B}, \mathrm{F} \\
\quad 3 \mathrm{~A} ; 5 \mathrm{~A}\end{array}$ & Modeling land-use/land-cover change & Ongoing $^{2}$ & $\begin{array}{l}\text { Greater sage grouse, } \\
\text { pygmy rabbit, mule } \\
\text { deer; all focal habitats }\end{array}$ & $\begin{array}{l}\text { Status \& trends, policy/outreach, } \\
\text { energy resource development }\end{array}$ & \\
\hline $1 \mathrm{~A}-\mathrm{C} ; 2 \mathrm{~B}, \mathrm{~F}$ & Assessing energy resources & Completed & N/A & $\begin{array}{l}\text { Science foundation, } \\
\text { policy/outreach, energy } \\
\text { resource development }\end{array}$ & \\
\hline $1 \mathrm{~A}-\mathrm{C} ; 2 \mathrm{~B}, \mathrm{~F}$ & Mineral resources & Completed $^{4}$ & N/A & $\begin{array}{l}\text { Science foundation, } \\
\text { policy/outreach, energy } \\
\text { resource development }\end{array}$ & \\
\hline $\begin{array}{l}\text { 1A-B; 2A-F; 3A- } \\
\quad \mathrm{C} ; 4 \mathrm{C} ; 5 \mathrm{~A}-\mathrm{D}\end{array}$ & $\begin{array}{l}\text { Wind energy and wildlife in southwest } \\
\text { Wyoming }\end{array}$ & New & $\begin{array}{l}\text { At-risk birds, bats, and } \\
\text { other wildlife }\end{array}$ & $\begin{array}{l}\text { Science foundation, } \\
\text { policy/outreach, energy } \\
\text { resource development }\end{array}$ & 18 \\
\hline
\end{tabular}

\footnotetext{
${ }^{1}$ Scientific names of focal species: Animals-Greater sage-grouse (Centrocercus urophasianus), Brewer's sparrow (Spizella breweri), sagebrush sparrow (Artemisiospiza nevadensis), sage thrasher (Oreoscoptes montanus), pygmy rabbit (Brachylagus idahoensis), mule deer (Odocoileus hemionus), mountain sucker (Catostomus platyrhynchus), mottled sculpin (Cottus bairdii), Colorado River cutthroat trout (Oncorhynchus clarkii pleuriticus). Plants-sagebrush species (Artemisia spp.), mountain-mahogany (Cercocarpus montanus), curl-leaf mountain-mahogany (Cercocarpus ledifolius), western serviceberry (Amelanchier alnifolia), chokecherry (Prunus virginiana), antelope bitterbrush (Purshia tridentata), aspen (Populus tremuloides).

${ }^{2}$ New project phase or new focus and title.

${ }^{3}$ Activities that entail ongoing work, including monitoring, analysis, development of data-processing scripts, and (or) other product development, but which did not have tangible outcomes or products in FY2016 are not included in this report. See prior annual reports for more information on these projects.

${ }^{4}$ Major phase of project completed in FY2016, but some final products continue to be produced.
} 
Table 2. Summary of U.S. Geological Survey science and technical development projects conducted in fiscal year 2016 for the Wyoming Landscape Conservation Initiative (WLCl).-Continued

\begin{tabular}{|c|c|c|c|c|c|}
\hline $\begin{array}{l}\text { Management needs } \\
\text { and objectives } \\
\text { addressed }\end{array}$ & Project title & $\begin{array}{l}\text { Status at } \\
\text { end of } \\
\text { FY2016 }\end{array}$ & $\begin{array}{l}\text { Focal species and (or) } \\
\text { habitat }^{1}\end{array}$ & $\begin{array}{l}\text { Intended and potential } \\
\text { applications of project outcomes }\end{array}$ & Page no. \\
\hline \multicolumn{6}{|c|}{ Long-Term Monitoring } \\
\hline $\begin{array}{l}\text { 2A-F; 2A-B; 3A- } \\
\quad \mathrm{C} ; 4 \mathrm{~A}, \mathrm{C} ; 5 \mathrm{~A}-\mathrm{E}\end{array}$ & $\begin{array}{l}\text { Framework and indicators for long-term } \\
\text { monitoring (including leadership and } \\
\text { support for the Interagency Monitoring } \\
\text { Team) }\end{array}$ & Ongoing & All focal habitats & $\begin{array}{l}\text { Status \& trends, science } \\
\text { foundation, policy/outreach }\end{array}$ & 20 \\
\hline $1 \mathrm{~A}, \mathrm{~B} ; 2 \mathrm{~B}, \mathrm{E}$ & $\begin{array}{l}\text { Time-series analysis of multiresolution } \\
\text { imagery to quantify sagebrush defoliation } \\
\text { and mortality in southwestern Wyoming }\end{array}$ & Ongoing & $\begin{array}{l}\text { Sagebrush species; } \\
\text { sagebrush steppe }\end{array}$ & $\begin{array}{l}\text { Status \& trends, science } \\
\text { foundation }\end{array}$ & 23 \\
\hline $\begin{array}{l}\text { 1A-B; 3B-D; 4C; } \\
\quad 5 B, C\end{array}$ & $\begin{array}{l}\text { Remote sensing and vegetation inventory and } \\
\text { monitoring }\end{array}$ & Ongoing & $\begin{array}{l}\text { Sagebrush species; } \\
\text { sagebrush steppe }\end{array}$ & $\begin{array}{l}\text { Status \& trends, science } \\
\text { foundation }\end{array}$ & 25 \\
\hline 1A-B; 4C; 5B-D & $\begin{array}{l}\text { Long-term monitoring of surface water, } \\
\text { groundwater, and water quality }\end{array}$ & Ongoing & Riparian, aquatic & $\begin{array}{l}\text { Status \& trends, science } \\
\text { foundation }\end{array}$ & 27 \\
\hline 1A-B; 4C; 5B-D & $\begin{array}{l}\text { Analysis of long-term groundwater elevation } \\
\text { data and geologic description }\end{array}$ & Completed $^{4}$ & Aquatic & $\begin{array}{l}\text { Status \& trends, science } \\
\text { foundation, energy resource } \\
\text { development }\end{array}$ & \\
\hline 1A-B; 4C; 5B-D & $\begin{array}{l}\text { Evaluation of groundwater interaction with } \\
\text { small streams in the western Green River } \\
\text { Basin to enhance understanding of aquatic } \\
\text { communities }\end{array}$ & Ongoing & Aquatic & $\begin{array}{l}\text { Status \& trends, science } \\
\text { foundation, energy resource } \\
\text { development }\end{array}$ & 29 \\
\hline 1A-B; 4C; 5B-D & $\begin{array}{l}\text { Synoptic streamflow measurements on the } \\
\text { New Fork and Green Rivers }\end{array}$ & Ongoing $^{2}$ & Aquatic & $\begin{array}{l}\text { Status \& trends, science } \\
\text { foundation }\end{array}$ & 30 \\
\hline
\end{tabular}

\footnotetext{
${ }^{1}$ Scientific names of focal species: Animals-Greater sage-grouse (Centrocercus urophasianus), Brewer's sparrow (Spizella breweri), sagebrush sparrow (Artemisiospiza nevadensis), sage thrasher (Oreoscoptes montanus), pygmy rabbit (Brachylagus idahoensis), mule deer (Odocoileus hemionus), mountain sucker (Catostomus platyrhynchus), mottled sculpin (Cottus bairdii), Colorado River cutthroat trout (Oncorhynchus clarkii pleuriticus). Plants-sagebrush species (Artemisia spp.), mountain-mahogany (Cercocarpus montanus), curl-leaf mountain-mahogany (Cercocarpus ledifolius), western serviceberry (Amelanchier alnifolia), chokecherry (Prunus virginiana), antelope bitterbrush (Purshia tridentata), aspen (Populus tremuloides).

${ }^{2} \mathrm{New}$ project phase or new focus and title.

${ }^{3}$ Activities that entail ongoing work, including monitoring, analysis, development of data-processing scripts, and (or) other product development, but which did not have tangible outcomes or products in FY2016 are not included in this report. See prior annual reports for more information on these projects.

${ }^{4}$ Major phase of project completed in FY2016, but some final products continue to be produced.
} 
Table 2. Summary of U.S. Geological Survey science and technical development projects conducted in fiscal year 2016 for the Wyoming Landscape Conservation Initiative (WLCl). - Continued

\begin{tabular}{|c|c|c|c|c|c|}
\hline $\begin{array}{l}\text { Management needs } \\
\text { and objectives } \\
\text { addressed }\end{array}$ & Project title & $\begin{array}{l}\text { Status at } \\
\text { end of } \\
\text { FY2016 }\end{array}$ & $\begin{array}{l}\text { Focal species and (or) } \\
\text { habitat }^{1}\end{array}$ & $\begin{array}{l}\text { Intended and potential } \\
\text { applications of project outcomes }\end{array}$ & Page no. \\
\hline \multicolumn{6}{|c|}{ Effectiveness Monitoring } \\
\hline $\begin{array}{l}\text { 1A; 2A-C,E-F; } \\
\text { 3A-C; 4A-D; } \\
\text { 5A-E }\end{array}$ & $\begin{array}{l}\text { Plant phenology metrics to evaluate sagebrush } \\
\text { in the WLCI region (previous title-- } \\
\text { Applying greenness indices to evaluate } \\
\text { sagebrush in the WLCI region) }\end{array}$ & Ongoing & $\begin{array}{r}\text { Sagebrush species; } \\
\text { sagebrush steppe }\end{array}$ & $\begin{array}{l}\text { Status \& trends, science } \\
\text { foundation, policy/outreach }\end{array}$ & 31 \\
\hline $\begin{array}{l}\text { 1A; 2A-D,F; 3A- } \\
\text { C; 4A-D; 5A-E }\end{array}$ & $\begin{array}{l}\text { Mapping mixed mountain shrub communities } \\
\text { to support WLCI conservation planning and } \\
\text { effectiveness monitoring of habitat } \\
\text { treatments }\end{array}$ & Ongoing & $\begin{array}{l}\text { Mountain-mahogany and } \\
\text { curl-leaf mountain- } \\
\text { mahogany, western } \\
\text { serviceberry, } \\
\text { chokecherry, antelope } \\
\text { bitterbrush; mixed } \\
\text { mountain shrubland }\end{array}$ & $\begin{array}{l}\text { Status \& trends, science } \\
\text { foundation, policy/outreach }\end{array}$ & 33 \\
\hline $\begin{array}{l}\text { 1A; 2A-C,E-F; } \\
\text { 3A-C; 4A-D; } \\
\text { 5A-E }\end{array}$ & $\begin{array}{l}\text { Greater sage grouse use of vegetation } \\
\text { treatments }\end{array}$ & Ongoing $^{3}$ & $\begin{array}{l}\text { Greater sage grouse; } \\
\text { sagebrush steppe } \\
\text { (grouse brood-rearing/ } \\
\text { nesting habitat) }\end{array}$ & $\begin{array}{l}\text { Status \& trends, science } \\
\text { foundation, policy/outreach }\end{array}$ & \\
\hline $\begin{array}{l}\text { 1A; 2A-F; 3A-C; } \\
\text { 4A-D; 5A-E }\end{array}$ & $\begin{array}{l}\text { Landscape assessment and monitoring of } \\
\text { semiarid woodlands in the Little Mountain } \\
\text { ecosystem }\end{array}$ & Completed $^{4}$ & Aspen & $\begin{array}{l}\text { Status \& trends, science } \\
\text { foundation, policy/outreach }\end{array}$ & 34 \\
\hline $\begin{array}{l}\text { 1A; 2A-F; 3A-C; } \\
\text { 4A-D; 5A-E }\end{array}$ & $\begin{array}{l}\text { Aspen regeneration associated with } \\
\text { mechanical removal of subalpine fir }\end{array}$ & Ongoing $^{3}$ & Aspen, conifer species & $\begin{array}{l}\text { Status \& trends, science } \\
\text { foundation, policy/outreach }\end{array}$ & \\
\hline $\begin{array}{l}\text { 1A; 2A-F; 3A-D; } \\
\text { 4A-D; 5A-E }\end{array}$ & $\begin{array}{l}\text { Herbivory, stand condition, and regeneration } \\
\text { rates of aspen on burned and unburned plots }\end{array}$ & Ongoing $^{3}$ & Aspen & $\begin{array}{l}\text { Status \& trends, science } \\
\text { foundation, policy/outreach }\end{array}$ & \\
\hline \multirow{2}{*}{\multicolumn{6}{|c|}{$\begin{array}{l}{ }^{1} \text { Scientific names of focal species: Animals-Greater sage-grouse (Centrocercus urophasianus), Brewer's sparrow (Spizella breweri), sagebrush sparrow } \\
\text { (Artemisiospiza nevadensis), sage thrasher (Oreoscoptes montanus), pygmy rabbit (Brachylagus idahoensis), mule deer (Odocoileus hemionus), mountain sucker } \\
\text { (Catostomus platyrhynchus), mottled sculpin (Cottus bairdii), Colorado River cutthroat trout (Oncorhynchus clarkii pleuriticus). Plants-sagebrush species } \\
\text { (Artemisia spp.), mountain-mahogany (Cercocarpus montanus), curl-leaf mountain-mahogany (Cercocarpus ledifolius), western serviceberry (Amelanchier } \\
\text { alnifolia), chokecherry (Prunus virginiana), antelope bitterbrush (Purshia tridentata), aspen (Populus tremuloides). }\end{array}$}} \\
\hline & & & & & \\
\hline \multicolumn{6}{|c|}{$\begin{array}{l}{ }^{3} \text { Activities that entail ongoing work, including monitoring, analysis, development of data-processing scripts, and (or) other product development, but which did } \\
\text { not have tangible outcomes or products in FY2016 are not included in this report. See prior annual reports for more information on these projects. }\end{array}$} \\
\hline
\end{tabular}


Table 2. Summary of U.S. Geological Survey science and technical development projects conducted in fiscal year 2016 for the Wyoming Landscape Conservation Initiative (WLCl). - Continued

\begin{tabular}{|c|c|c|c|c|c|}
\hline $\begin{array}{l}\text { Management needs } \\
\text { and objectives } \\
\text { addressed }\end{array}$ & Project title & $\begin{array}{l}\text { Status at } \\
\text { end of } \\
\text { FY2016 }\end{array}$ & $\begin{array}{l}\text { Focal species and (or) } \\
\text { habitat }^{1}\end{array}$ & $\begin{array}{l}\text { Intended and potential } \\
\text { applications of project outcomes }\end{array}$ & Page no. \\
\hline \multicolumn{6}{|c|}{ Mechanistic Studies of Wildlife } \\
\hline $\begin{array}{l}\text { 1A-B; 2A-F; 3A- } \\
\quad \mathrm{C} ; 4 \mathrm{C} ; 5 \mathrm{~A}-\mathrm{D}\end{array}$ & $\begin{array}{l}\text { Modeling habitat associations and } \\
\text { distribution of pygmy rabbits }\end{array}$ & Ongoing $^{3}$ & $\begin{array}{l}\text { Pygmy rabbit; sagebrush } \\
\text { steppe }\end{array}$ & $\begin{array}{l}\text { Status \& trends, science } \\
\text { foundation, energy resource } \\
\text { development }\end{array}$ & 36 \\
\hline $\begin{array}{l}\text { 1A-B; } 2 \mathrm{~A}-\mathrm{F} ; 3 \mathrm{~A}- \\
\mathrm{C} ; 4 \mathrm{C} ; 5 \mathrm{~A}-\mathrm{D}\end{array}$ & $\begin{array}{l}\text { Modeling greater sage grouse population } \\
\text { responses to landscape changes }\end{array}$ & Ongoing & $\begin{array}{l}\text { Greater sage grouse; } \\
\text { sagebrush steppe, sage } \\
\text { grouse core areas }\end{array}$ & $\begin{array}{l}\text { Status \& trends, science } \\
\text { foundation, policy/outreach, } \\
\text { energy resource development }\end{array}$ & 37 \\
\hline $\begin{array}{l}\text { 1A-B; } 2 \mathrm{~A}-\mathrm{F} ; 3 \mathrm{~A}- \\
\mathrm{C} ; 4 \mathrm{C} ; 5 \mathrm{~A}-\mathrm{D}\end{array}$ & $\begin{array}{l}\text { Mechanistic understanding of energy } \\
\text { resource development effects on songbirds }\end{array}$ & Ongoing & $\begin{array}{l}\text { Brewer's sparrow, } \\
\text { sagebrush sparrow, } \\
\text { sage thrasher; } \\
\text { sagebrush steppe }\end{array}$ & $\begin{array}{l}\text { Status \& trends, policy/outreach, } \\
\text { energy resource development }\end{array}$ & 39 \\
\hline $\begin{array}{l}\text { 1A-B; 2A-F; 3A- } \\
\quad \mathrm{C} ; 4 \mathrm{C} ; 5 \mathrm{~A}-\mathrm{D}\end{array}$ & $\begin{array}{l}\text { Identifying threshold levels of development } \\
\text { that impede Wyoming mule deer } \\
\text { migrations }\end{array}$ & Ongoing & $\begin{array}{l}\text { Mule deer; mixed } \\
\text { mountain shrubland } \\
\text { (crucial winter habitat) }\end{array}$ & $\begin{array}{l}\text { Status \& trends, policy/outreach, } \\
\text { energy resource development }\end{array}$ & 41 \\
\hline $\begin{array}{l}\text { 1A-B; 2A-F; 3A- } \\
\quad \text { C; 4C; } 5 \mathrm{~A}-\mathrm{D}\end{array}$ & $\begin{array}{l}\text { Drivers of native fish community response to } \\
\text { oil and gas development (previous title- } \\
\text { Influence of energy resource development } \\
\text { on native fish communities) }\end{array}$ & Ongoing & $\begin{array}{l}\text { Mountain sucker, mottled } \\
\text { sculpin, Colorado River } \\
\text { cutthroat trout, and all } \\
\text { other native fish } \\
\text { species; aquatic, } \\
\text { riparian }\end{array}$ & $\begin{array}{l}\text { Science foundation, } \\
\text { policy/outreach, energy } \\
\text { resource development }\end{array}$ & 43 \\
\hline
\end{tabular}

${ }^{1}$ Scientific names of focal species: Animals-Greater sage-grouse (Centrocercus urophasianus), Brewer's sparrow (Spizella breweri), sagebrush sparrow (Artemisiospiza nevadensis), sage thrasher (Oreoscoptes montanus), pygmy rabbit (Brachylagus idahoensis), mule deer (Odocoileus hemionus), mountain sucker (Catostomus platyrhynchus), mottled sculpin (Cottus bairdii), Colorado River cutthroat trout (Oncorhynchus clarkii pleuriticus). Plants-sagebrush species (Artemisia spp.), mountain-mahogany (Cercocarpus montanus), curl-leaf mountain-mahogany (Cercocarpus ledifolius), western serviceberry (Amelanchier alnifolia), chokecherry (Prunus virginiana), antelope bitterbrush (Purshia tridentata), aspen (Populus tremuloides).

${ }^{2}$ New project phase or new focus and title.

${ }^{3}$ Activities that entail ongoing work, including monitoring, analysis, development of data-processing scripts, and (or) other product development, but which did not have tangible outcomes or products in FY2016 are not included in this report. See prior annual reports for more information on these projects.

${ }^{4}$ Major phase of project completed in FY2016, but some final products continue to be produced. 
Table 2. Summary of U.S. Geological Survey science and technical development projects conducted in fiscal year 2016 for the Wyoming Landscape Conservation Initiative (WLCl). - Continued

\begin{tabular}{|c|c|c|c|c|c|}
\hline $\begin{array}{l}\text { Management needs } \\
\text { and objectives } \\
\text { addressed }\end{array}$ & Project title & $\begin{array}{l}\text { Status at } \\
\text { end of } \\
\text { FY2016 }\end{array}$ & $\begin{array}{l}\text { Focal species and (or) } \\
\text { habitat }^{1}\end{array}$ & $\begin{array}{l}\text { Intended and potential } \\
\text { applications of project outcomes }\end{array}$ & Page no. \\
\hline \multicolumn{6}{|c|}{ Data and Information Management } \\
\hline 5D; 6A-D & Data management framework and catalog & Ongoing & N/A & $\begin{array}{l}\text { Science foundation, } \\
\text { policy/outreach }\end{array}$ & 45 \\
\hline $6 B-D$ & $\begin{array}{l}\text { Outreach and graphic products: web } \\
\text { application development for data } \\
\text { visualization }\end{array}$ & Ongoing $^{3}$ & N/A & $\begin{array}{l}\text { Science foundation, } \\
\text { policy/outreach }\end{array}$ & \\
\hline
\end{tabular}

${ }^{1}$ Scientific names of focal species: Animals-Greater sage-grouse (Centrocercus urophasianus), Brewer's sparrow (Spizella breweri), sagebrush sparrow (Artemisiospiza nevadensis), sage thrasher (Oreoscoptes montanus), pygmy rabbit (Brachylagus idahoensis), mule deer (Odocoileus hemionus), mountain sucker (Catostomus platyrhynchus), mottled sculpin (Cottus bairdii), Colorado River cutthroat trout (Oncorhynchus clarkii pleuriticus). Plants-sagebrush species (Artemisia spp.), mountain-mahogany (Cercocarpus montanus), curl-leaf mountain-mahogany (Cercocarpus ledifolius), western serviceberry (Amelanchier alnifolia), chokecherry (Prunus virginiana), antelope bitterbrush (Purshia tridentata), aspen (Populus tremuloides)

${ }^{2}$ New project phase or new focus and title.

${ }^{3}$ Activities that entail ongoing work, including monitoring, analysis, development of data-processing scripts, and (or) other product development, but which did not have tangible outcomes or products in FY2016 are not included in this report. See prior annual reports for more information on these projects.

${ }^{4}$ Major phase of project completed in FY2016, but some final products continue to be produced. 


\section{Highlights of FY2016 USGS WLCI Science Accomplishments}

In FY2016, there were 25 active USGS WLCI science-based projects. Of these 26 projects, one project was new for FY2016, and three were completed by the end of the fiscal year (though final products were still in preparation or review). USGS WLCI research resulted in 4 products published in peer-reviewed professional journals or USGS publications series; 10 manuscripts begun but not completed in the fiscal year (in preparation, in review, or in press); and over 20 presentations given at professional meetings or conferences. The FY2016 activities also included updates to long-term monitoring datasets; meetings with stakeholders and collaborators; and field data collection, data analysis, and modeling tasks on more than 20 of these projects.

\section{Baseline Synthesis}

Five of the USGS WLCI projects were associated with collecting information for baseline synthesis. Baseline Synthesis projects directly address WLCI management needs to identify key drivers of change (particularly energy and minerals development, invasive species, and climate change), the condition and distribution of key wildlife species and habitats, and species' habitat requirements. They also support several objectives listed under the management needs to evaluate the effectiveness of restoration, reclamation, and mitigation activities and to develop an integrated inventory and monitoring strategy.

In FY2016, we assisted the WLCI Coordination Team with updating the WLCI Conservation Action Plan and the associated habitat treatment spatial database with information from FY2015 habitat projects as part of the Comprehensive Assessment (p. 17). We also assisted with the Bureau of Land Management (BLM) 2015 WLCI annual report and provided maps and other materials to support evaluations and rankings of 2017 WLCI conservation projects.

By the end of FY2016, we had completed assessments of energy resources, and assessments of mineral resources had neared completion (final products were still in the review/publication stage). A map of sand and gravel deposits was in review, and the WLCI region had been included in USGS Scientific Investigations Report 2016-5089-E, which details geology and mineral resources of sagebrush focal areas of the western United States (Wilson and others, 2016). Additionally, a paper describing USGS scientist S. Garman's use of data from previous WLCI years on land use/land cover and the distribution of oil and gas resources to simulate the effects of oil and gas development on wildlife was in review with the journal "Environmental Modeling and Assessment."

We also initiated a study on the effects of wind energy on wildlife in the WLCI region (p. 18). We designed the study to address the lack of information on research activities pertaining to wildlife near wind developments in Wyoming; these data gaps make it difficult to effectively plan

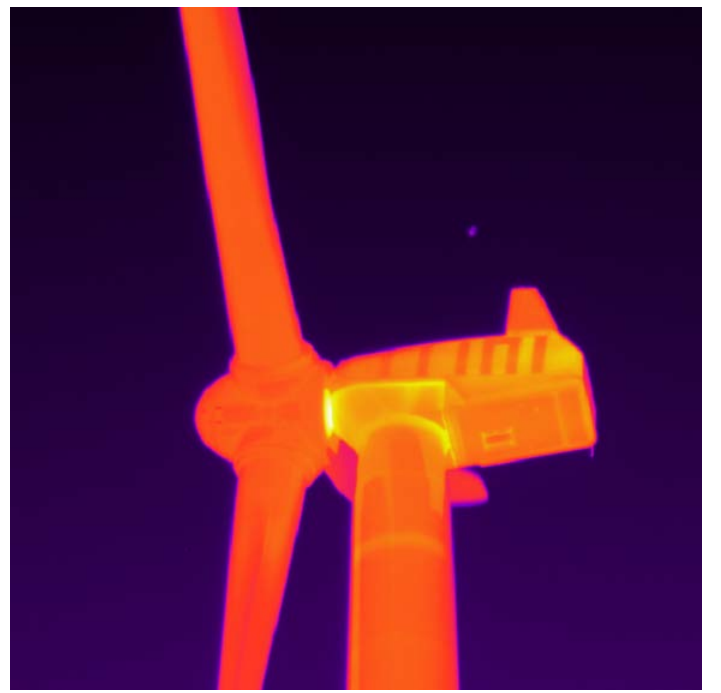

Thermal imagery of an animal flying above a wind turbine. Photograph by Robb Diehl, U.S. Geological Survey. 
research on wind energy development in the WLCI area. In this first year, we identified project objectives and research needs primarily by attending the 2016 WLCI research meeting and the Wind Wildlife Research Meeting. We scheduled project initiation and product development for FY2017.

\section{Long-Term Monitoring}

Seven long-term monitoring projects focusing on water and vegetation continued in FY2016. Our Long-Term Monitoring projects directly address the WLCI management need to develop an integrated inventory and monitoring strategy and indirectly address management needs to identify key drivers of change, the condition and distribution of key wildlife species and habitats, and species' habitat requirements. We use emerging technologies and develop and test innovative methods for maximizing the efficiency and efficacy of monitoring efforts.

In FY2016, the USGS Monitoring Team continued work to disseminate resource status and trend information and improve field sampling, data aggregation, and analytical approaches. This team had a USGS circular in review at the end of the fiscal year. USGS scientists also investigated the recovery of sagebrush habitats in the WLCI region from disturbance related to oil and gas development (p. 20). USGS ecologists continued analysis of sagebrush defoliation and mortality over a two-decade time span by using satellite imagery to identify spatial and temporal variability in plant productivity (p. 23). We continued monitoring of 260 ground vegetation transects and compared the resulting data to vegetation change measured by using Landsat satellite imagery (p. 25). This effort included the creation of eight new Landsat-based component products that estimate vegetation cover and height for the entire WLCI region. Ongoing monitoring activities added an additional year of data to long-term datasets on surface water and groundwater quality (p. 27), and a new, short-term study added to our understanding of how withdrawals of shallow groundwater might affect in-river flows (p. 30). USGS hydrologists also continued to measure streamflow data from 25 sites on small streams in the Western Green River Basin; these data provide insights into the mechanisms of sustaining small streams (p. 29) in the upper parts of watersheds, which in turn support a greater understanding of the effects of energy development on native fish communities (p. 43).

\section{Effectiveness Monitoring}

USGS scientists continued many projects in FY2016 that were designed to monitor and evaluate the effectiveness of habitat conservation actions and provide tools in support of mechanistic studies of wildlife. Effectiveness Monitoring projects directly address the WLCI management needs to (1) evaluate the effectiveness of habitat treatment projects, as well as restoration, reclamation, and mitigation activities; (2) develop an integrated inventory and monitoring strategy; (3) evaluate habitat treatments and best management practices; (4) make monitoring data available to WLCI partners; and (5) develop and test innovative methods for maximizing the efficiency and efficacy of monitoring efforts. Our Effectiveness Monitoring activities also indirectly support objectives associated with the management need to identify the condition and distribution of some key habitats and wildlife habitat needs and use. 


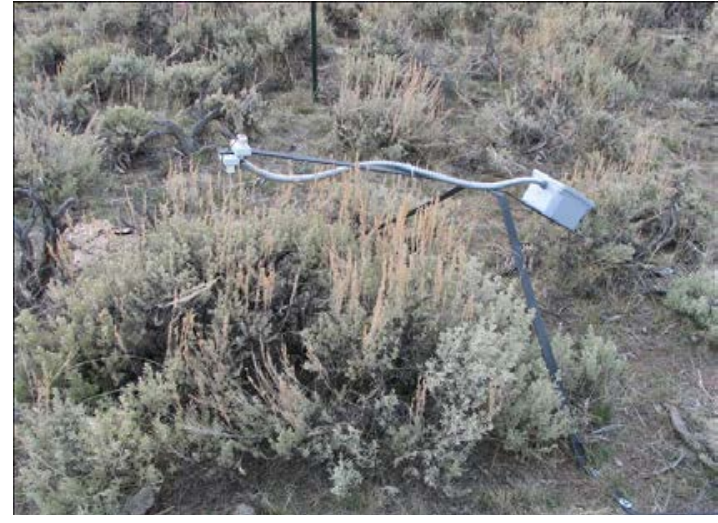

Mantis sensing platform for measuring greenness of vegetation. Photograph by Geneva Chong, U.S. Geological Survey.

In FY2016, USGS researchers collaborated with the Wyoming Cooperative Fish and Wildlife Research Unit and the Wyoming Migration Initiative to examine how plant phenology and use by mule deer (Odocoileus hemionus) differs between sagebrush treatment areas and surrounding untreated sagebrush (Artemisia spp.) (p. 31). This work resulted in six presentations at regional and international conferences on the relation between ungulate migration and plant phenology. We continued collection of field data to monitor vegetation structure and herbivory on aspen (Populus tremuloides) treatments, cheatgrass (Bromus tectorum) cover in habitat treatments, and greater sage grouse (Centrocercus urophasianus) use of vegetation treatments. We continued mapping of mixed mountain shrub communities in the WLCI region and developed and implemented protocols for measuring herbivory in mountain-mahogany (Cercocarpus montanus) communities using dendrologic methods (p. 33). We completed analysis of Landsat data to determine trends in the condition of semiarid woodlands in the Little Mountain Ecosystem in an effort to better understand effects of disturbance in this system. USGS ecologists are using this analysis to determine the feasibility of using remote-sensing data as a tool to monitor abrupt and gradual change in aspen forests and to identify areas most susceptible to change (p. 34). In FY2016, this work resulted in several presentations at professional meetings and an article in the journal "Forest Ecology and Management."

\section{Mechanistic Studies of Wildlife}

Mechanistic Studies of Wildlife projects directly address the WLCI management needs to evaluate the responses of wildlife to development and to identify the condition and distribution of key wildlife species and habitats, and species' habitat requirements. They also help to identify key drivers of change and some of the objectives associated with developing an integrated inventory and monitoring strategy. In FY2016, USGS scientists, along with university and State partners, continued work on five focal wildlife species/communities (pygmy rabbits [Brachylagus idahoensis], greater sage grouse, mule deer, sagebrush songbirds, and native fish). We continued analysis of pygmy rabbit habitat and population trends, drafted manuscripts describing this work, and presented talks on the effects of oil and gas development on pygmy rabbits at professional meetings (p. 36). Our research on sage grouse continued its focus on population viability models and analysis of population trends (p. 37). We completed a statewide population viability analysis and a statewide hierarchical cluster analysis of population trends, and we developed population viability models for the WLCI region to evaluate effects of climate change and energy development on sage grouse populations. We submitted manuscripts on the effects of oil and gas development on sage grouse to "Journal of Wildlife Management" and on patterns in sage grouse populations related to grazing records to "Ecological Applications.” Both papers were accepted for publication in 2017.

Researchers and partners at our Cooperative Fish and Wildlife Research Unit at University of Wyoming continued our work on mule deer migration and songbird and native fish communities. We used Global Positioning System (GPS) movement data to evaluate whether 
different types of development influence the ability of mule deer (p. 41) to track plant green-up ("surf the green wave"). We made two presentations at professional meetings related to this work and prepared a manuscript for submission to the journal "Ecological Applications." We continued nest-monitoring of sagebrush songbird species (p. 39) to determine survival and to identify nest predators and their abundance. We collected data to test hypotheses for increased rodent nest predator abundance with increased energy development. We gave two presentations and prepared a manuscript for submission to "Journal of Applied Ecology" on sagebrush songbird nest predation. We collected a fifth year of fish community data (p. 43) from streams in the WLCI region as part of our work on drivers of native fish community response to oil and gas development. We expanded our focus to include stream characterization and resource availability at all study sites, and we expanded our fish sampling to measure physiological and immunological response for mountain sucker (Catostomus platyrhynchus) and mottled sculpin (Cottus bairdii).

\section{Data and Information Management}

Data and Information Management activities directly address the management need to develop a data clearinghouse (data catalog) and information management framework. These activities directly and indirectly support and provide access to results of most USGS WLCI projects that address primary WLCI management needs, particularly the need to develop an integrated inventory and monitoring system (a major component of the data catalog). In FY2016, the USGS Information Management Team presented information to WLCI scientists on how USGS tools and resources can be used to fulfill the requirements of new USGS policies regarding data release, data management, and data visualization (p. 45). The team presented examples that demonstrate the standard approaches used to document and deliver data in ways that allow for efficient and interactive visualizations of information. 


\section{Project Reports-Baseline Synthesis}

\section{Application of Comprehensive Assessment to Support Decision Making and Conservation Actions}

The Comprehensive Assessment is a collaborative, two-part effort to support WLCI data needs and efforts. Part one entails directing data synthesis and assessment activities to support Local Project Development Teams and the WLCI Coordination Team in their efforts to develop conservation priorities and strategies, identify priority areas for future conservation actions, support evaluation and ranking of conservation projects, and evaluate the ways in which proposed habitat projects relate to WLCI priorities, both spatially and ecologically. Part two of the Comprehensive Assessment entails a multidisciplinary Integrated Assessment (IA) of (1) data relating to WLCI priorities and (2) resources designed to support decisions at the WLCI programmatic level and conservation planning at landscape scales. The IA includes identifying areas of high conservation and restoration value and those with high development potential, based on the current landscape. The IA also may be used to consider scenarios of potential future development for evaluating the conservation and restoration potential of a given area. In FY2016, we assisted the WLCI Coordination Team with updating the WLCI Conservation Action Plan and the associated habitat treatment spatial database with information from FY2015 habitat projects. We also assisted with the 2015 BLM WLCI annual report and provided maps and other materials to support evaluations and rankings of 2017 WLCI conservation projects. On the WLCI web page, we initiated new ecology-based themes to reorganize USGS science in a way that improves communication of and navigation through USGS accomplishments. This effort is also used to summarize key findings from select USGS studies by themes.

\section{Products Completed in FY2016}

- Updated WLCI Conservation Action Plan with WLCI conservation accomplishments and associated geographic information system (GIS) information.

Contacts: Patrick J. Anderson, 970-226-9488, andersonpj@usgs.gov; Timothy J. Assal, 970226-9134, assalt@usgs.gov; Zachary H. Bowen, 970-226-9218, bowenz@usgs.gov 


\section{Wind Energy and Wildlife in Southwest Wyoming}

New project in FY2016.

Wind energy developments have increased recently in southwest Wyoming, where their effects on wildlife remain poorly understood. Wind currently meets 4 percent of U.S. energy needs and is expected to account for 35 percent of demands by 2050. Significant growth of wind energy will likely continue within the WLCI focal area because Wyoming ranks first in the United States for wind resources (AWS Truepower, LLC, 2010). Wind farms have been in southwest Wyoming since the 1970s, and 12 farms were in operation or development within the WLCI focal area as of 2012 (Biewick and Jones, 2012). The largest wind farm in North America, known as the Chokecherry and Sierra Madre Wind Project, is in development near Rawlins, Wyoming, and will operate 1,000 turbines distributed across 220,000 acres of public and private lands. A comprehensive assessment of wind and wildlife issues in southwest Wyoming is needed for the WLCI to address stakeholder concerns about wind farms and to further incorporate wind into the WLCI research program on energy and wildlife.

Wind development may affect wildlife through habitat alteration, behavioral avoidance, and fatal collisions with turbines. Recent research has quantified wildlife losses to collisions with turbines at many facilities worldwide, but population-level effects remain poorly understood. Researchers have tested means to minimize wildlife fatalities through turbine curtailment, wildlife deterrents, and strategic selection of development sites. Most research has been concerned with turbine collisions by bats and birds, especially eagles, but some efforts have evaluated the effects on species unlikely to collide with turbines, such as sage grouse and pronghorn (Antilocapra americana). Information about research activities on wildlife populations around wind developments in Wyoming and access to related data is currently scattered, which makes effective research and conservation planning in the WLCI focal area difficult.

The focus of this project is an assessment of the status of wind energy development and its potential effects on wildlife in southwest Wyoming. We will synthesize existing information on wind energy development, species of concern, and research activities in this region. This information will be useful for guiding WLCI research on wind-related issues and advancing WLCI objectives to identify key drivers of change, locate sensitive areas, and evaluate effects of energy development on wildlife. We will compile relevant information through a literature review and engagement with the BLM, the Wyoming Game and Fish

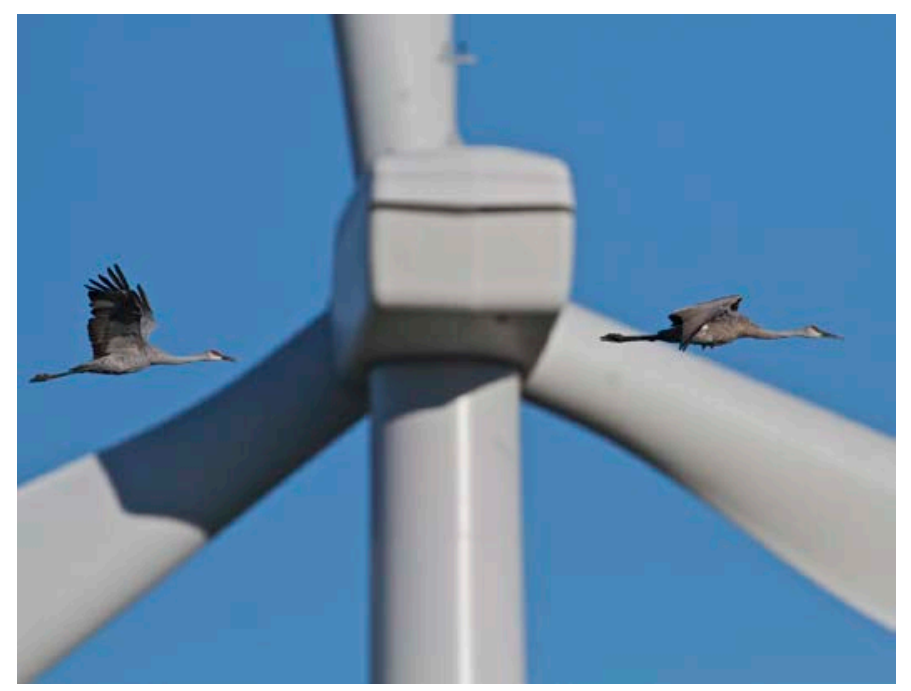

Sandhill cranes navigate a wind farm. Photograph by $\mathrm{J}$. Bartholmai, U.S. Geological Survey.

Department, industry, nongovernmental organizations, environmental consulting groups, and USGS Science Centers involved with wind energy in Wyoming. Land managers will have access to this consolidated information so that, when planning for wind developments, they can ensure projects are of an appropriate size and in a location that will have the least effect on native wildlife populations. 


\section{Objectives}

1. Synthesize existing information on wind developments and their effects on wildlife in southwest Wyoming.

2. Identify species vulnerable to wind development and spatial overlap with wind facilities.

3. Identify research and management needs concerning wildlife and wind energy.

\section{Methods}

This project will compile and synthesize relevant information on wind and wildlife through a review of literature and online resources. Consultation with agencies, industry, and other stakeholders will help identify research needs and data access issues. Species' risk to wind developments will be evaluated through spatial analyses of species' ranges, habitat maps, and the distribution of wind farms.

\section{Study Area}

The study area is the WLCI focal area, where investigation will focus on existing and upcoming wind farms. Emphasis on the Chokecherry and Sierra Madre Wind Project near Rawlins is expected because it is located partially on lands administered by the BLM and preconstruction research opportunities are still possible.

Work Accomplished in FY2016 and Implications of Initial Findings

We identified research needs and project objectives during the annual WLCI research meeting in June 2016. In November 2016, Aaron Johnston attended the Wind Wildlife Research Meeting XI presented by the American Wind Wildlife Institute to identify research issues, current studies, stakeholders, and contacts. Approximately 450 scientists, managers, activists, and industry representatives attended the conference. Most research presented at the conference took place outside of the WLCI focal area. Long-term projects to assess effects of the Chokecherry and Sierra Madre Wind Project on mule deer and sage grouse are underway by private consulting groups, but data sharing with the WLCI is uncertain. Limited or no access to ongoing outside research underscores the need for the WLCI to identify and prioritize research on assessing the effects of the wind energy industry on wildlife.

\section{Products Completed in FY2016}

- $\quad$ Project initiation and product development scheduled to begin in FY2017.

Contact: Aaron Johnston, 406-994-7158, ajohnston@usgs.gov 


\section{Project Reports—Long-Term Monitoring}

\section{Framework and Indicators for Long-Term Monitoring}

The USGS Monitoring Team brings together research specialists and habitat and wildlife biologists to inform and develop methods and defensible approaches to monitor statuses and trends in populations and habitats across the WLCI region. It is working to better disseminate resource status and trend information, while simultaneously working to improve both field sampling approaches and data aggregation and analytical approaches. To this end, we assembled a six-page fact sheet (in press at end of FY2016, published in FY2017) that describes some of the important monitoring activities being conducted within the WLCI region and the information gained from these efforts. The goal for this document is to improve support for integrated monitoring efforts, improve communication and coordination among partners, and encourage cooperative activities that inform adaptive management.

USGS scientists are conducting several research projects focused on monitoring and assessing natural and human-caused disturbances in the sagebrush ecosystem, thereby providing important insights into resilience and recovery of native vegetation. We used a database of 1,135 well-pad locations across the landscape and the mapped distribution of sagebrush, herbaceous vegetation, and bare ground to document the recovery of important components of habitat to predisturbance conditions. Well-pad information included dates associated with disturbance and reclamation (because of data limitations, all pads included in the study were initiated in or after 1985). Based on a recovery index, which represents the ratio of the sagebrush cover estimate in the current year to the estimate from before drilling began at the same location, we observed an increasing effect of time since disturbance on sagebrush cover (fig. 2). Our observations indicated that, even after several decades of regrowth, most sites have not recovered to predisturbance habitat conditions. Local environmental conditions also affected recovery. Lowelevation sites demonstrated a positive response to higher spring precipitation, but recovery rates declined as maximum temperatures increased. Conversely, at higher elevations, we saw a positive response to high spring precipitation when coincident with warm spring temperatures. This response may be related to seedling establishment that is limited by soil moisture at lower elevations and by cold temperatures and snow depth at higher elevations (Nelson and others, 2014). In FY2017, we will continue our efforts to better account for important environmental factors that create differences in recovery rates. 


\section{Recovery since attenuation of drilling activity}

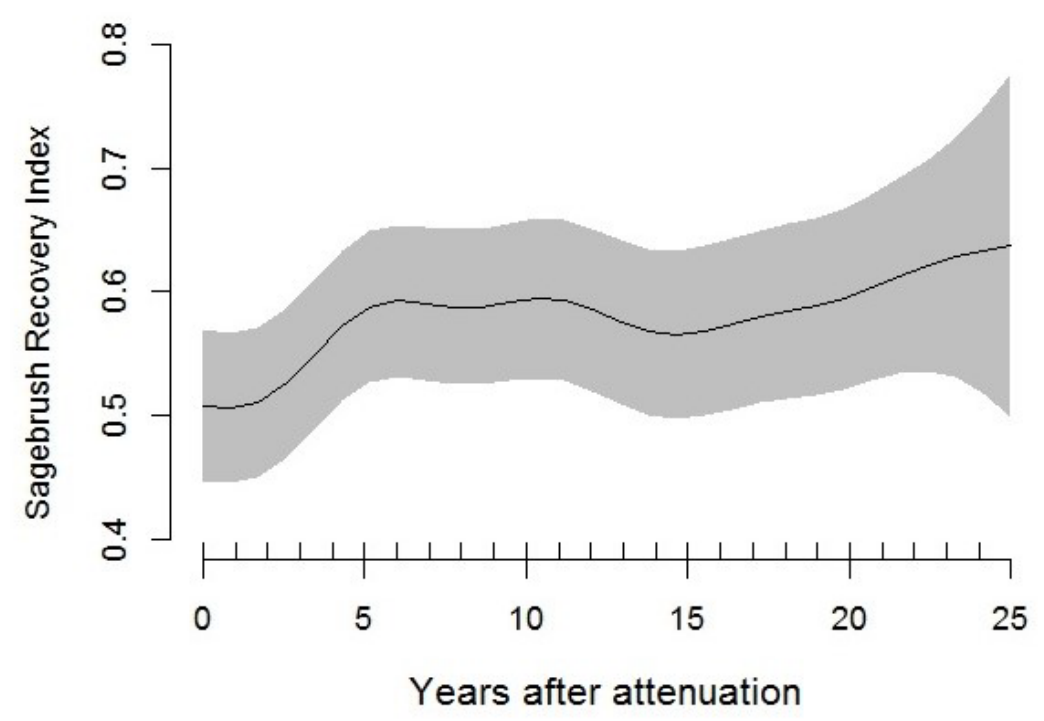

Figure 2. Sagebrush Recovery Index (ratio of sagebrush cover after disturbance/reclamation to cover before disturbance) in southwest Wyoming related to years after attenuation of drilling activity.

We are also working to better understand the recovery of sagebrush ecosystems after fire. In FY2016, field crews visited 24 postfire locations documented by WLCI partners. Half of these locations received postfire treatments (a variety of site preparation and seeding treatments), and half recovered naturally. Although an increased sample size is needed to improve this assessment, preliminary results indicate considerable variability among sites and several important trends in habitat conditions that can inform management and habitat monitoring efforts. Frequency of plants (count per each sample unit of three 50-meter [m] transects; includes both shrubs and herbaceous) appears to peak at 60-70 percent in the first 20 years after disturbance, then declines to 40-50 percent. Our analysis of seeded and nonseeded locations indicated similar recovery patterns in both groups, with nonseeded locations demonstrating a greater abundance of plants and a peak frequency of 70-85 percent, compared to 60-70 percent for seeded locations. Perennial grasses on seeded sites were abundant (frequent) in the first 16 years after disturbance at 20-45 percent but were reduced to 10 percent by year 20. Conversely, nonseeded sites generated a high frequency of perennial grasses in the first 10 years at 20-40 percent, and they maintained these levels for at least 28 years (maximum age in this sample). Shrubs did not demonstrate consistent postfire response in the seeded and nonseeded locations that we observed. Most sites had very low shrub cover, but some showed a shrub frequency of 20-40 percent (including non-sagebrush species). We confirmed these trends by using a canopy gap assessment, which indicated a significant difference between seeded and nonseeded sites. Nonseeded sites showed a gradual decrease in canopy gap length, stabilizing at 50-60 centimeters $(\mathrm{cm})$ after approximately 16 years, but seeded sites showed an increasing trend from near $60 \mathrm{~cm}$ to more than $100 \mathrm{~cm}$ after 55 years. In addition to postfire treatment effects, we observed an inverse relation between shrub cover and perennial grass cover related to aspect. East and southeast aspects showed greater frequency of shrubs (20-40 percent) and lower 
frequency of perennial grasses (10-20 percent), and south, southwest, and west aspects demonstrated very low shrub frequency (10 percent or less) but high abundance of perennial grasses (30-50 percent). Although preliminary, our results have important implications for postfire recovery efforts as well as understanding how local topography and disturbance history may interact to affect habitat patterns and resilience to disturbance.

Our work is helping to address primary WLCI objectives, especially development of integrated inventory and monitoring strategies, as well as additional needs and objectives identified by partners at the 2006-2007 WLCI Workshops, including (1) identifying key drivers of change, (2) identifying condition and distribution of key wildlife species and habitats, and (3) evaluating wildlife and livestock responses to development. This work can help identify those methods that are most successful at recovering sagebrush following natural fires, as well as methods for effective use of prescribed fire to improve sagebrush habitat.

\section{Products Completed in FY2016}

- Monitoring the Southwestern Wyoming Landscape-U.S. Geological Survey fact sheet (6 p.), in press at end of FY2016. (Published FY2017: Manier, D.J., Anderson, P.J., Assal, T.J., Chong, G.W., and Melcher, C.P., 2017, Monitoring the southwestern Wyoming landscape - A foundation for management and science: U.S. Geological Survey Fact Sheet 2017-3030, 6 p., https://doi.org/10.3133/fs20163030.)

Contacts: Daniel J. Manier, 970-226-9466, manierd@usgs.gov 


\section{Time-Series Analysis of Multiresolution Imagery to Quantify Sagebrush Defoliation and Mortality in Southwestern Wyoming}

Sagebrush mortality and defoliation have been reported in the upper Green River Basin in recent years (Clause and Randall, 2014). There is concern that defoliation and (or) mortality events represent additional stressors on sagebrush habitats that could have negative effects on sagebrush-obligate species. The extent, mechanism, and frequency of these events are unknown at this time, but mortality has been reported within sage grouse core areas and crucial pronghorn winter habitat. Numerous causes have been suggested, but recent drought (2012-13) is the likely mechanism of mortality at the landscape scale in this water-limited ecosystem. Ongoing research that uses remote sensing to describe long-term characteristics of sagebrush ecosystems has been successful (see p. 25); however, the short timeframe (for example, intraseasonal) associated with sagebrush defoliation or mortality events requires analysis over smaller intervals. Furthermore, an understanding of the variability in patterns of productivity with respect to climate is essential to exploit landscape-scale remote sensing for detection of subtle changes associated with mortality in this sparse, uniformly vegetated ecosystem. Sagebrush communities are a WLCI focal ecosystem, and this work seeks to expand our research capacity to monitor the status and trends of sagebrush communities with respect to drought. In this study, we assessed time-series data for detection of subtle changes in sagebrush ecosystem productivity associated with mortality at landscape and local scales.

In FY2016, we used the standardized precipitation index to characterize drought conditions and Moderate Resolution Imaging Spectroradiometer (MODIS) satellite imagery (250-m resolution; Brown and others, 2015) to characterize broad characteristics of growing season productivity. We calculated per-pixel, monthly anomalies over a 17-year period (20002016) to identify the spatial and temporal variability in productivity during the growing season. Negative anomalies highlighted dramatic declines in productivity during the 2012 and 2013 growing seasons. However, some of these large negative anomalies persisted during the 2014 growing season, indicating lag effects of drought (fig. 3) that may be associated with areas of woody plant mortality. In FY2017, we planned to investigate trends within these areas at local scales using metrics derived from Landsat satellite imagery (30-m resolution). Furthermore, we planned to relate our findings with field measurements from other WLCI research projects (where possible) and assess relations with local biophysical properties. 


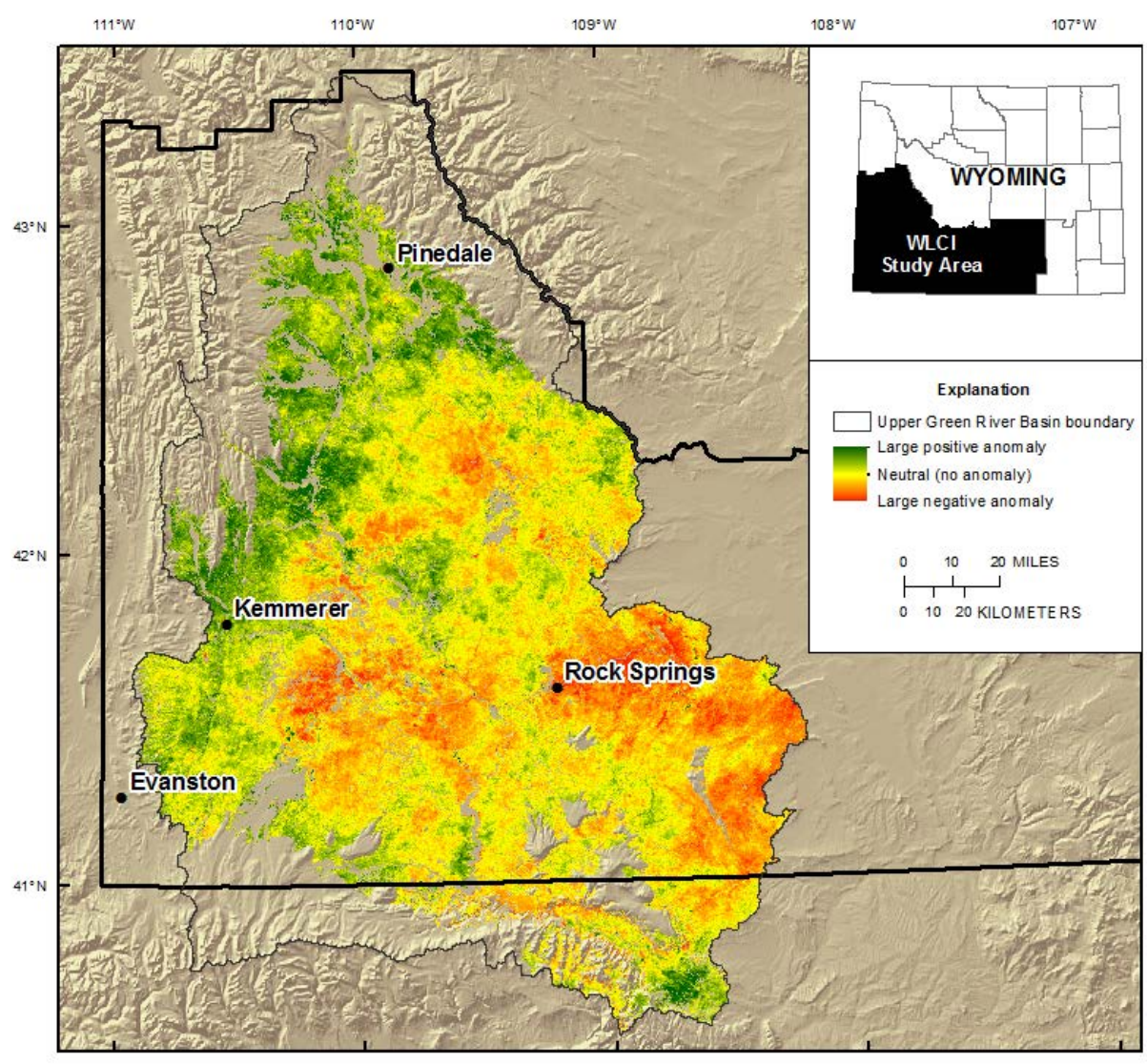

Figure 3. Cumulative net anomalies of sagebrush ecosystem productivity for the 2014 growing season.

\section{Products Completed in FY2016}

- Met with WLCI partners to identify additional sagebrush mortality observations and share initial findings.

- Assembled 17-year MODIS record of productivity from weekly composite images $(n=884)$.

- Analyzed the relation between sagebrush productivity and temperature and precipitation variables.

Contact: Timothy J. Assal, 970-226-9134, assalt@usgs.gov 


\section{Remote Sensing and Vegetation Inventory and Monitoring}

The focus of this work is to use remote-sensing tools and protocols for monitoring longterm changes in vegetation cover across the WLCI region. This information is crucial for understanding patterns of change within sagebrush habitats across the WLCI region, including historical changes and potential future trajectories of change. We characterize vegetation by component cover, and we focus especially on five components of vegetation cover-shrubs overall, sagebrush, herbaceous vegetation, litter, and bare ground-which are quantified at 1 percent intervals. Based on samples collected both in the field and from satellite imagery, we can evaluate and quantify the amount and distribution of change in these target components over time. This work and the associated products represent the operational vegetation monitoring effort for the WLCI and provide input to a broad spectrum of on-going WLCI research and applications.

During FY2016, we monitored and analyzed vegetation change in the WLCI region in several ways from both ground and satellite measurement. We measured long-term vegetationmonitoring plots across 260 marked transects in two intensive study sites on the ground, along with 2-m and 30-m satellite data. These transects have been ground- and satellite-measured every year since 2008, offering both valuable monitoring insight and a means to understand and validate patterns of annual ground-level change compared to the remotely sensed protocols. Our preliminary analysis of ground-transect measurements in study site 1 taken between 2008 and 2016 showed an increasing trend in both total shrub and sagebrush canopy, with 53 percent of the shrub transects and 72 percent of the sagebrush transects showing a significant change. Conversely, bare ground was trending downward over this same period, with 28 percent of transects showing a significant change. We are currently researching the patterns of this transect ground change, and analyzing these change patterns across the broader WLCI landscape using remote sensing protocols.

During FY2016, we remapped the entire WLCI region into new Landsat-scale predictions of eight fractional components based on extensive field data and imagery collected in the summer of 2015. The WLCI region was remapped for several reasons:

1. The original version was based on 2006 imagery. The new version uses 2015 imagery, so it provides updated estimates to account for the 9 years of change.

2. The new update was part of an effort that extended beyond Wyoming, so the new updated maps now match other products being developed in other regions.

3. New methods were developed during the mapping that should improve the accuracy of these and future products.

The resulting product should be comparable with the older product to some extent but not identical. The new product, however, will incorporate additional "back in time" product development to 1984, so users ultimately will have both current base products and historical products that are completely integrated and comparable, eventually rendering the 2006 base map obsolete. The historical change analysis will extend back to 1984.

These products were released to the public in March 2017, as planned, and serve as the primary vegetation data layers for a broad variety of WLCI science and management activities (https://www.mrlc.gov/nlcdshrub.php). Additionally, using existing remotely sensed products, we evaluated recovery rates after disturbance from 1985 to 2015 for sagebrush habitat components. Preliminary analyses measured the recovery rate of disturbed well pads to recover to original undisturbed vegetation cover. Our analysis of time-stamped maps of predicted 
vegetation cover before and after disturbances suggests that after 25 years, sagebrush has only recovered to 60 percent of its original condition. We found that recovery rates are faster at higher elevations on more mesic sites. We are also continuing our evaluation of recovery from fires and vegetation treatments.

\section{Products Completed in FY2016}

- Sustained long-term monitoring of 260 marked transect plots across two intensive study areas for ground measurement of annual change. These plots have been measured annually since 2008.

- Completed eight new Landsat-based component products for the entire WLCI region, representing the nominal year of 2015. New component products include estimates of shrub, sagebrush, big sagebrush, bare ground, herbaceous, annual herbaceous, litter, shrub height and sagebrush height.

- Initiated a new back-in-time analysis of historical change in the WLCI region back to 1984 using the updated 2015 component base products.

Contacts: Collin G. Homer, 208-426-5213, homer@usgs.gov; Cameron L. Aldridge, 970-2269433, aldridgec@usgs.gov 


\section{Long-Term Monitoring of Surface Water, Groundwater, and Water Quality}

Riparian and aquatic ecosystems in semiarid landscapes like southwest Wyoming contribute substantially to regional biodiversity. Long-term monitoring data that describe streamflow, surface-water quality, and groundwater levels are needed for assessing possible effects of changes in land use, land cover, and climate on those ecosystems. With WLCI funding, we have monitored streamflow and surface-water quality at four stream sites and groundwater levels at four well sites (fig. 4). We selected monitoring sites to provide baseline characterization of the upper Green River Basin and the Muddy Creek watersheds. Additionally, we are using data collected at the four stream sites to describe water-quality trends. All data were collected according to USGS methods (Wagner and others, 2006; Kenney, 2010; Sauer and Turnipseed, 2010; Turnipseed and Sauer, 2010; U.S. Geological Survey, variously dated).

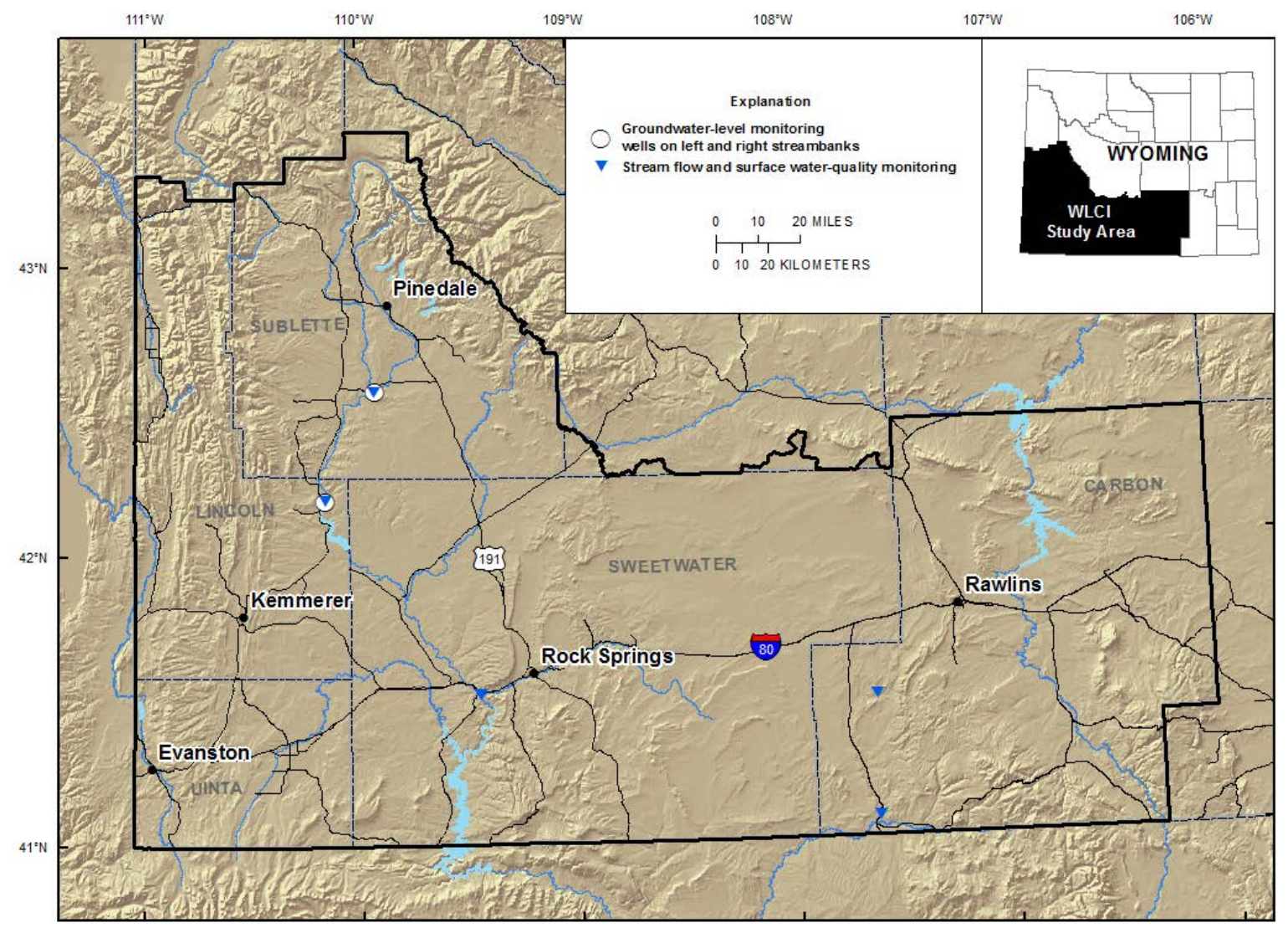

Figure 4. Locations of U.S. Geological Survey field-based study areas associated with long-term monitoring projects during fiscal year 2016 in the Wyoming Landscape Conservation Initiative (WLCI) region. 
This project helps to address the WLCI management need to develop an integrated inventory and monitoring strategy designed to evaluate overall effectiveness of WLCI on-the-ground habitat projects and support assessments of cumulative effects of change. During FY2016, in addition to the data collection described above, we collected additional surface-water quality and quantity data in the WLCI region in cooperation with the State of Wyoming, the BLM, and the Bureau of Reclamation. When combined, these data create a larger water-resources dataset that we can use to support resource management and research in

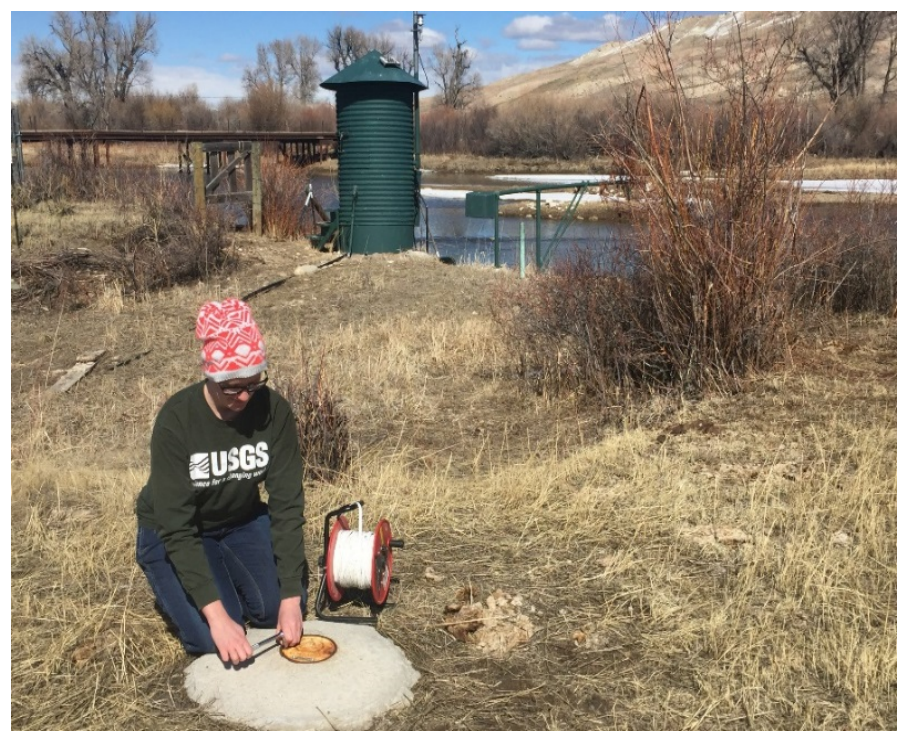

Preparing to measure water level in streambank monitoring well near New Fork River. Photograph by Cheryl Eddy-Miller, U.S. Geological Survey. the WLCI study area and beyond.

\section{Products Completed in FY2016}

- Groundwater data from the continuous, real-time groundwater streamgage sites are available at http://wy-mt.water.usgs.gov/projects/GW_streamgaging/index.html.

- For all monitoring sites, preliminary data are available in real time, and for each site there is an annual report that finalizes and summarizes the data (table 3).

Table 3. Products published in fiscal year 2016 related to work on long-term monitoring of surface water, groundwater, and water quality in the Wyoming Landscape Conservation Initiative region. [WY, Wyoming]

\begin{tabular}{|c|c|}
\hline Real-time and water-quality data & Water-year summary report \\
\hline \multicolumn{2}{|c|}{ New Fork River near Big Piney, WY } \\
\hline $\begin{array}{l}\text { http://waterdata.usgs.gov/wy/nwis/uv/ } \\
\text { ?site_no }=09205000\end{array}$ & $\begin{array}{l}\text { http://waterdata.usgs.gov/nwis/wys_rpt/ } \\
\text { ?site_no=09205000 }\end{array}$ \\
\hline \multicolumn{2}{|c|}{ Green River near Green River, WY } \\
\hline $\begin{array}{l}\text { http://waterdata.usgs.gov/wy/nwis/uv/ } \\
\text { ?site_no }=09217000\end{array}$ & $\begin{array}{l}\text { http://waterdata.usgs.gov/nwis/wys_rpt/ } \\
\text { ?site_no }=09217000\end{array}$ \\
\hline \multicolumn{2}{|c|}{ Muddy Creek above Olson Draw, near Dad, WY } \\
\hline $\begin{array}{l}\text { http://waterdata.usgs.gov/wy/nwis/uv/ } \\
\text { ?site_no }=09258050\end{array}$ & $\begin{array}{l}\text { http://waterdata.usgs.gov/nwis/wys_rpt/ } \\
\text { ?site_no=09258050 }\end{array}$ \\
\hline \multicolumn{2}{|c|}{ Muddy Creek below Young Draw, near Baggs, WY } \\
\hline $\begin{array}{l}\text { http://waterdata.usgs.gov/wy/nwis/uv/ } \\
\text { ?site_no=09258980 }\end{array}$ & $\begin{array}{l}\text { http://waterdata.usgs.gov/nwis/wys_rpt/ } \\
\text { ?site_no=09258980 }\end{array}$ \\
\hline
\end{tabular}

Contact: Cheryl A. Eddy-Miller, 307-775-9167, cemiller@usgs.gov; Kirk A. Miller, 307-7759168,kmiller@usgs.gov 


\section{Evaluation of Groundwater Interaction with Small Streams in the Western Green River Basin to Enhance Understanding of Aquatic Communities}

Energy development has occurred on the eastern flank of the Wyoming Range since the early 1900s, and the geographical extent of development has increased in recent years. WLCI coinvestigator Annika Walters is evaluating the effects of development on native fish species. An evaluation of groundwater interaction with small streams in the western Green River Basin and precise streamflow measurements are important components to assist Walters with determining the health of all aquatic species. An understanding of streamflow levels and the stream sections where streamflow is sustained throughout the year will elucidate changes and differences in aquatic communities.

We collected streamflow data during November 2015, April 2016, and June 2016 at sites in the South Beaver Creek, Fogarty Creek, and Dry Piney Creek drainages. We are using these data, in addition to streamflow data collected in FY2015 and FY2017, to provide insights into the mechanisms of sustaining small streams in the upper parts of watersheds, such as groundwater return flow or recent precipitation. These insights will help our coinvestigator interpret the aquatic species distribution data, as well as describe mechanisms of sustaining small streams in the upper parts of watersheds. These small streams can be critical to the survival of native species, and increasing our understanding of what controls the streamflow will support resource management decisions in the study area.

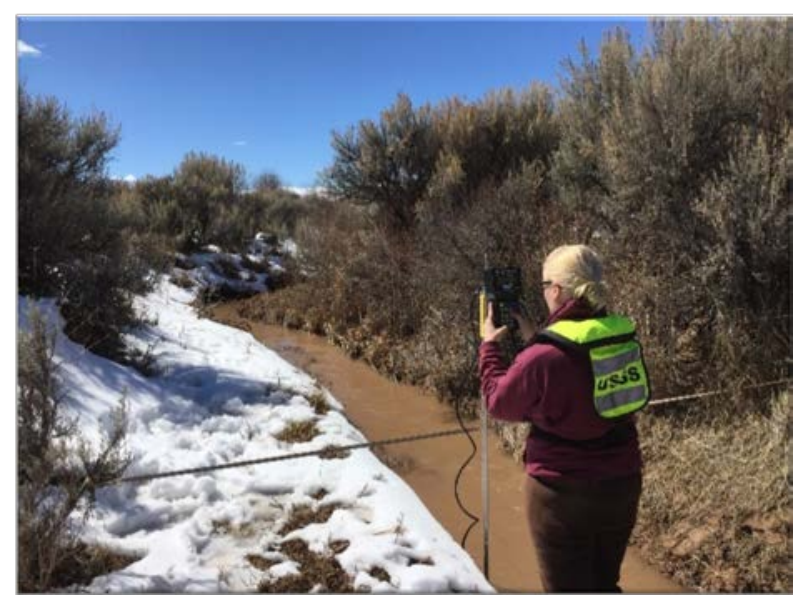

Measuring streamflow in Dry Piney Creek during the initial winter snowmelt. Photograph by Cheryl EddyMiller, U.S. Geological Survey.

\section{Products Completed in FY2016}

- All streamflow measurements collected from the 25 sites in the study are available online at https://wy-mt.water.usgs.gov/projects/wlci/gw_interaction/index.html.

Contacts: Cheryl A. Eddy-Miller, 307-775-9167, cemiller@usgs.gov; Kirk Miller, 307-7759168, kmiller@usgs.gov; Jerrod D. Wheeler, 307-856-3771, ext. 212, jwheele@usgs.gov 


\section{Synoptic Streamflow Measurements on the New Fork and Green Rivers}

New project in FY2016.

Measuring streamflow using a synoptic technique involves the collection of streamflow

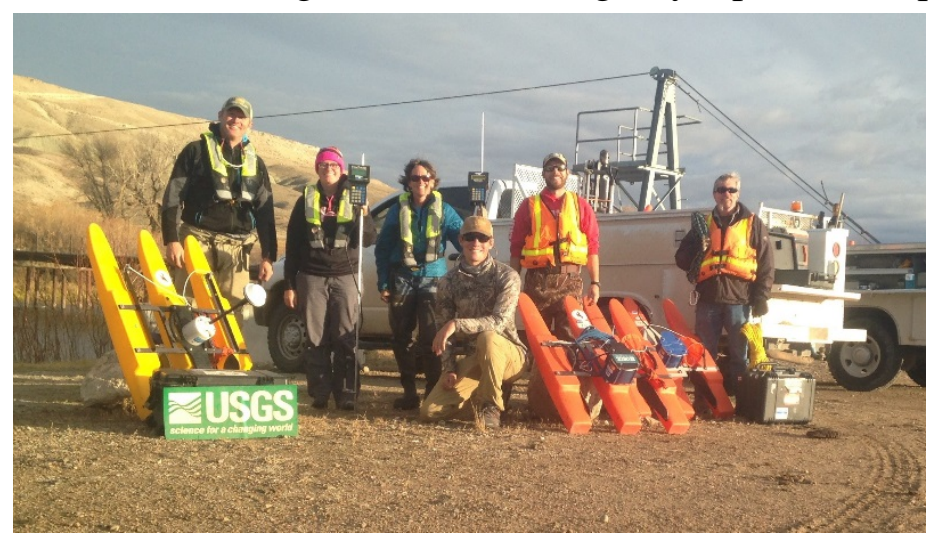

We assembled a crew of six technicians and scientists, skilled with all types of flow-measurement equipment, to measure streamflow at a large number sites in a short amount of time. Photograph by Joseph Stephens, U.S. Geological Survey.

upper Green River area will help local managers, such as the BLM and local conservation districts, understand how changes such as increased withdrawals of shallow groundwater might affect flows in the river. Additionally, these data complement the site-specific data collected at area streamgages and aid in the understanding of the extent to which shallow and deeper groundwater interact. The cumulative knowledge gained from the different studies provide a better understanding of the entire hydrologic system.

\section{Products Completed in FY2016}

- Streamflow data were processed, quality assured, and made available to public at https://wy-mt.water.usgs.gov/projects/wlci/synoptic/index.html. Rivers. data from many locations during a short period of time. Thus, it creates a "snapshot" of changes along a stream at a given point in time. These data provide a longitudinal understanding of where the rivers gain and lose water from/to groundwater along their lengths (Wheeler and Eddy-Miller, 2005). During October 19-22, 2015, we collected nearly 60 measurements from 19 sites on the New Fork and Green

The understanding of the river and shallow groundwater systems in the

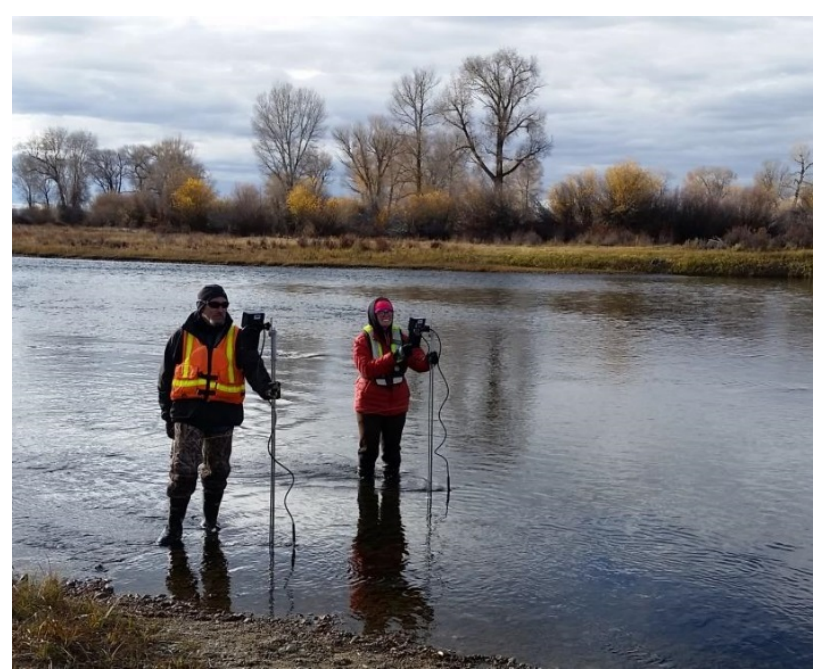

We made multiple measurements at each site to minimize the variability of each site's streamflow because the differences in streamflow between sites are often small. Photograph by Cheryl Eddy-Miller, U.S. Geological Survey.

Contact: Cheryl A. Eddy-Miller, 307-775-9167, cemiller@usgs.gov; Jerrod D. Wheeler, 307856-3771, ext. 212, jwheele@usgs.gov 


\section{Project Reports-Effectiveness Monitoring}

\section{Plant Phenology Metrics to Evaluate Sagebrush in the WLCI Region}

Previously titled "Applying Greenness Indices to Evaluate Sagebrush in the WLCI Region."

Weather and climate affect terrestrial wildlife habitat and wildlife fitness through their influences on plant productivity. Plant phenology — the timing of life-history events such as green-up, flowering, and senescence-provides one indicator of the timing and magnitude of productivity. Measuring and monitoring plant phenology and wildlife habitat use and fitness contribute specifically to evaluating and monitoring the effectiveness of management activities related to habitat quality. In particular, changes in phenology can affect animals that migrate over long distances and elevation ranges following plant green-up and senescence. As migration routes become constrained by development and human disturbance, a common response is for migrating animals to increase rate of movement, reduce stopover use, and occasionally detour around established routes. Thus, alterations to the behavior of animals during migration have the potential to modify their ability to track changing plant phenology across the landscape, also known as "surfing the green wave."

In FY2016, we continued collaboration with the Wyoming Cooperative Fish and Wildlife Research Unit on the Wyoming Range Mule Deer Project (see Identifying Threshold Levels of Development that Impede Wyoming Mule Deer Migrations, p. 41). One objective of this project is to quantify the benefits of migration including the use of stopover areas, which warrant management as critical habitat. We have found that drought interacts with deer's ability to track the most nutritious forage (surf the green wave): deer surf well overall, but they do better in a wet year (fig. 5). We are expanding our collaboration with the Wyoming Migration Initiative (www.migrationinitiative.org) to examine how sagebrush habitat treatment areas differ from surrounding sagebrush and if mule deer use them differently. We are using satellite data to measure plant phenology responses in treated (fire, herbicide, or mechanical removal) and untreated sagebrush, and we are using deer GPS collar locations to determine if deer use treated areas differently from untreated. Overall, our data and analyses will provide information to managers on habitat quality and animal use, which they can use to determine where to most

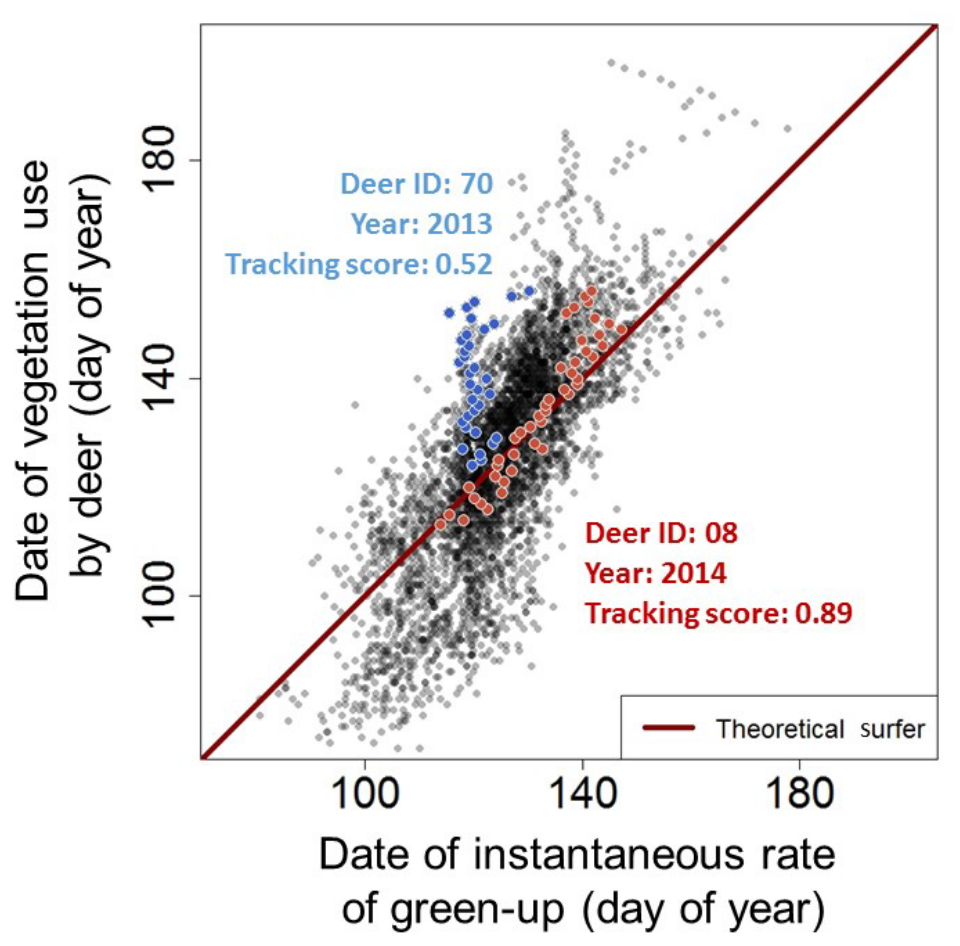

effectively implement conservation and mitigation projects. Our research will also advance the science of measuring and monitoring vegetation greenness especially as it relates to the effects of sagebrush habitat treatments and resulting habitat quality.

Figure 5. Use of vegetation by mule deer in western Wyoming relative to date of peak green-up during 2013 and 2014 mule deer migration season (roughly March 3 through July 16). Deer 
ID 70 was less efficient in tracking the green wave in a dry year (tracking score: $0.52 ; 2013$ ) than Deer ID 08 in a wet year (tracking score $0.89 ; 2014$ ). Diagonal line represents perfect tracking of green-up by a theoretical mule deer. Black dots represent tracking by all deer in the study. The effects of drought on vegetation productivity may alter the fitness benefits of migration. (ID, identifier)

\section{Products Completed in FY2016}

- Presentation-“What You See Depends on Your Point of View—Comparison of Greenness Indices Across Spatial and Temporal Scales and What That Means for Mule Deer Migration and Fitness,” B.W. Miller, Geneva Chong, Heidi Steltzer, Ellen Aikens, J.T. Morisette, Rick Shory, J.M. Kreinert, and Daniel Gurganus-American Geophysical Union Fall Meeting; San Francisco, Calif.; December 14-18, 2015.

- Presentation- "Does Drought Affect the Ability of Migratory Mule Deer to Surf the Green Wave?,” E.O. Aikens, K.L. Monteith, J.A. Merkle, Geneva Chong, Samantha Dwinnell, and M.J. Kauffman-22nd Annual Conference of The Wildlife Society; Winnipeg, Manitoba, Canada; October 17-21, 2015.

- Presentation- “Quantifying Greenscapes-Spatiotemporal Patterns of Phenology Shape Green Wave Surfing in Migratory Mule Deer,” E.O. Aikens, K.L. Monteith, J.A. Merkle, S.P. Dwinnell, and M.J. Kauffman—Large Herbivore Migrations in the Era of the Anthropocene; Oslo, Norway; April 18, 2016.

Contacts: Geneva W. Chong, 307-201-5425, geneva_chong@usgs.gov; Ellen Aikens, 307766-5415, ellen.aikens@gmail.com; Aaron Johnston, 406-994-7158, ajohnston@usgs.gov 


\section{Mapping Mixed Mountain Shrub Communities to Support WLCI Conservation Planning and Effectiveness Monitoring of Habitat Treatments}

The mixed mountain shrub community is one of five WLCI priority habitats and is associated with numerous WLCI conservation projects. However, relatively little is known about the current extent, condition, and trends of mountain shrub patches and mechanisms driving their condition. Monitoring data from selected stands indicate an overall decline in stand recruitment and vertical structure. Hypothesized causes of decline range from persistent drought to herbivory and, possibly, factors associated with increased energy resource development. Our long-term objectives are to map and measure the distribution and current condition of mixed mountain shrub communities and evaluate potential effects of habitat treatments (for example, projects to improve mule deer habitat), weather-related trends, increased energy resource development, and other change agents. Maps and other information from this work help to support WLCI partners with conservation planning and effectiveness monitoring of habitat treatments. Map products and associated information were shared with WLCI partners during Local Project Development Team meetings.

We continue to record the presence of mixed mountain shrub communities in the Big Piney-La Barge Area identified in the Wyoming Range Mule Deer Habitat Plan (Damm and Randall, 2012). We selected this area to take advantage of existing assessment and monitoring data acquired by WLCI partners. We used shrub presence data (Bowen and others, 2016) with satellite imagery to build models of site (habitat) suitability for mountain shrub occurrence (Bowen and others, 2013; Chong and others, 2015), and spatial data collected in 2014-2016 were used to improve map products completed in 2013 (Bowen and others, 2013).

In FY2016, we measured herbivory of mountain-mahogany leaders in early spring and collected mountain-mahogany stems from crucial and transitional range. We completed a protocol to evaluate mountain-mahogany establishment dates and growth and to reconstruct browsing histories. We initiated implementation of the protocol on stems collected during 2015 (Bowen and others, 2016).

\section{Products Completed in FY2016}

- Completed dendrologic herbivory protocol for mountain-mahogany.

- Completed 2016 vegetation sampling.

Contacts: Patrick J. Anderson, 970-226-9488, andersonpj@usgs.gov; Geneva W. Chong, 307201-5425, geneva_chong@usgs.gov 


\section{Landscape Assessment and Monitoring of Semiarid Woodlands in the Little Mountain Ecosystem}

The BLM and Wyoming Game and Fish Department regard the Little Mountain Ecosystem (LME) in southwestern Wyoming as a conservation priority. Since the mid-1990s, LME woodlands have been affected by several disturbance types, including wildfires and droughts. Management has included prescribed fire and mechanical thinning to rejuvenate decadent aspen stands and reduce conifer expansion in successional mixed-forest stands. To better understand disturbance effects on these woodlands, the BLM needs baseline information on these woodlands. Our goal is to provide that information, including woodland cover type and the extent, timing, and effects of various disturbance types on woodland productivity. A longterm objective of this work is to ascertain the feasibility of using archived satellite imagery to monitor abrupt and gradual changes in aspen forests and woodlands. Products will include datasets useful to the USGS and WLCI partners, and Local Project Development Teams may use the data to evaluate and prioritize aspen treatments. We are also using remote sensing to ascertain landscape-scale, long-term trends in woodland productivity, which will help to identify areas most susceptible to change. Finally, a broad aim of this work is to identify ecosystem response to disturbance and climate variability and to contribute to the literature of recent ecosystem change.

In FY2016, we completed the analysis using Landsat satellite data to determine changes in LME forest condition between 1985 and 2012. The driving concept of the analysis was to assess the relation between recent satellite imagery and the condition of vegetation on the ground. We then backcast the relation over the last 30 years to determine when and where change occurred. We assessed the relation between plant moisture (a proxy for plant productivity derived from satellite data) and a number of ground-based measurements. We hypothesized the long-term trajectory of plant moisture could be used to identify areas of forest that are resistant, persistent, or vulnerable to severe drought. Using plant moisture as the dependent variable and time as the explanatory variable, we mapped the direction of the slope in each regression equation across all pixels in the study area to identify trends in forest condition (fig. 6). Field plots with a negative trend had a lower live-tree density and higher amounts of standing dead and down trees compared to plots with no trend (Assal and others, 2016). This project was featured on the National Aeronautics and Space Administration (NASA) Landsat Science blog (http://landsat.gsfc.nasa.gov/new-paper-documents-spatial-and-temporal-trends-of-drought-in-asemi-arid-forest-ecosystem/). 

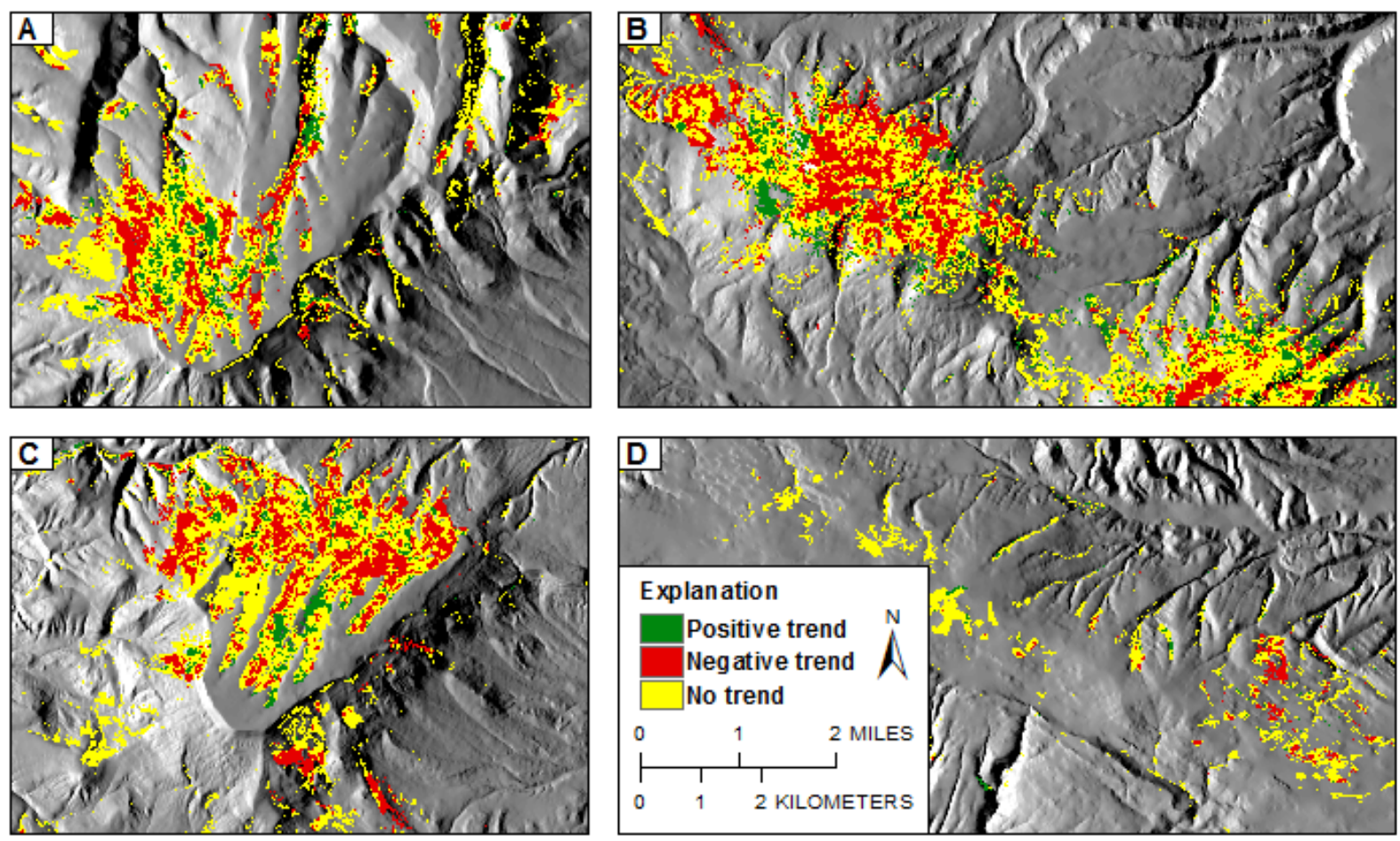

Figure 6. Trends in forest condition over the full time period of study (1985-2012) for locations within the Little Mountain Ecosystem. $A$, Little Mountain. $B$, Middle Mountain and portions of Diamond Peak. $C$, Pine Mountain. $D$, Cold Spring Mountain. (Positive and negative trends are significant at the 95 percent confidence level. Map panels are displayed at the same scale.)

\section{Products Completed in FY2016}

- Poster- “Spatial and Temporal Analysis of Drought Effects in a Heterogeneous SemiArid Forest Ecosystem,” Timothy Assal, P.J. Anderson, and Jason Sibold-American Geophysical Union Fall Meeting; San Francisco, Calif.; December 14-18, 2015.

- Assal, T.J., Anderson, P.J., and Sibold, Jason, 2016, Spatial and temporal trends of drought effects in a heterogeneous semi-arid forest ecosystem: Forest Ecology and Management, v. 365, p. 137-151, https://doi.org/10.1016/j.foreco.2016.01.017.

- WLCI science outreach through invited talks at the 2016 Aspen Days in Lander, Wyo., and the U.S. Forest Service Broader-scale Monitoring Workshop in Laramie, Wyo.

- Maps of trends in forest condition were disseminated to WLCI partners.

Contacts: Timothy J. Assal, 970-226-9134, assalt@usgs.gov; Patrick J. Anderson, 970-2269488, andersonpj@usgs.gov 


\section{Project Reports-Mechanistic Studies of Wildlife}

\section{Modeling Habitat Associations and Distribution of Pygmy Rabbits}

The Wyoming Game and Fish Department identified the pygmy rabbit (Brachylagus idahoensis) as a Species of Greatest Conservation Need in the state of Wyoming. Pygmy rabbit populations are vulnerable because of habitat loss and associated population declines. We have focused our research on identifying the range of sagebrush habitat types the pygmy rabbits inhabit, effects of landscape-scale habitat changes, and how natural gas development affects pygmy rabbit populations. Threats to pygmy rabbits include all forms of habitat loss and fragmentation in sagebrush systems. Our pygmy rabbit research in Wyoming has validated existing pygmy rabbit

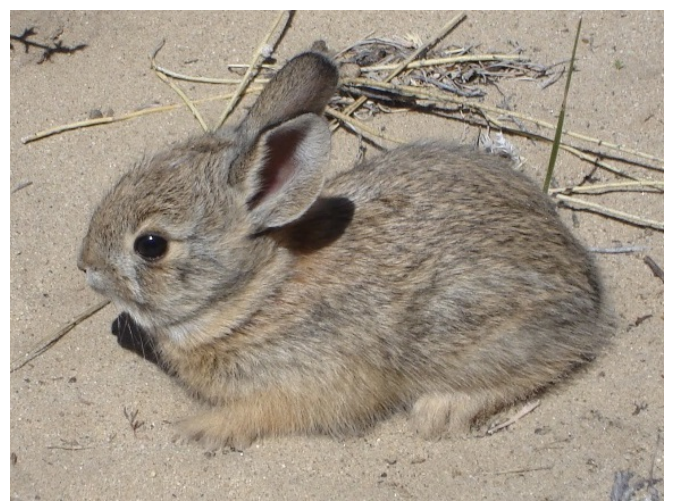

Pygmy rabbits range throughout the WLCI region. Photograph by Spencer Schell, U.S. Geological Survey. habitat maps, provided new distribution information, described variation in habitat quality, and provided information about the potential for spatial (overlap) conflicts between pygmy rabbits and both gas and wind energy resource development.

In FY2016, we analyzed data collected since 2010 and drafted manuscripts describing our findings.

\section{Products Completed in FY2016}

- Poster — “The Potential for Directional and Horizontal Drilling Technologies to Reduce Biophysical Impacts of Oil/Gas Development in Southwestern Wyoming,” S.L. Garman, S.S. Germaine, and C.L. Aldridge-2016 Working Without Borders: IndustryGovernment partnering in energy development Conference; Rawlins, Wyo.; October 2016.

Contact: Stephen S. Germaine, 970-226-9107, germaines@usgs.gov 


\section{Modeling Greater Sage Grouse Population Responses to Landscape Changes}

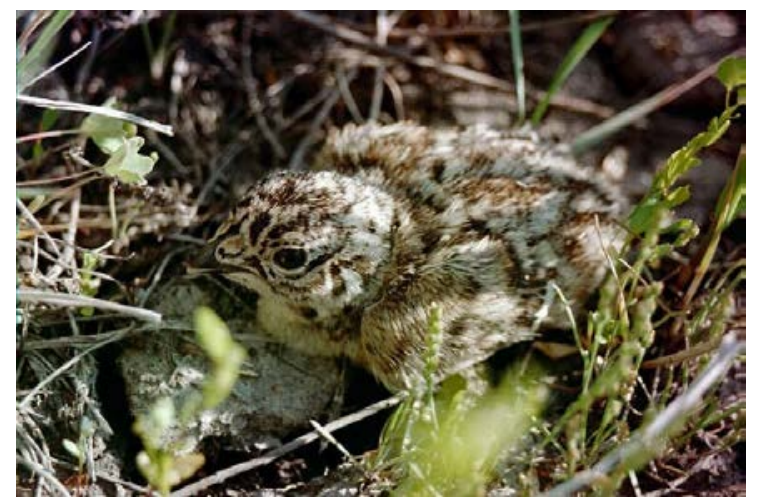

A sage grouse chick huddles amongst forbs. Photograph by Cam Aldridge, U.S. Geological Survey.

In FY2016, we continued to focus on the two main sage grouse research thrusts we have been working on within the WLCI. First, we completed the initial sage grouse population viability model framework for the state of Wyoming and have submitted a manuscript for publication. This model evaluates spatially where sage grouse persist, allowing us to evaluate the effectiveness of the core areas strategy in Wyoming at protecting sage grouse today and into the future. Approximately 75 percent of sage grouse in Wyoming inhabit the protected core areas for some or all life stages. Sage grouse using habitats outside the core areas also contribute to overall populations, yet significant population declines could occur in these unprotected areas. With that framework in place, we have completed analyses integrating spatially explicit oil and gas simulations developed for the WLCI by S.L. Garman and climate-induced changes in sagebrush habitat developed for the WLCI by C.G. Homer and C.L. Aldridge (see Remote Sensing and Vegetation Inventory and Monitoring, p. 25).

The second task of this research involves analyses of sage grouse population trends. Initially, we evaluated the effects of the timing of counts at leks on sage grouse population trends and found that data can be used from a wider window than previously believed, which allows a larger sample of lek counts to be considered (Monroe and others, 2016). We completed separate analyses evaluating how oil and gas development (Green and others, 2017) and grazing (Monroe and others, 2017) affect sage grouse population trends across the state. We found that grazing might have both positive and negative effects on sage grouse population trends depending on grazing timing and level, possibly reflecting the sensitivity of cool-season grasses to grazing during peak growth periods (Monroe and others, 2017). We also found that increasing density of oil and gas development within 6.4 kilometers of leks resulted in declining attendance of male sage grouse at those leks (Green and others, 2017). The results of this research provide land managers and planners with information on how grazing regimes might be implemented to benefit sage grouse populations and can also inform the locating of energy development activities to minimize effects on leks. Finally, we have been exploring how the sagebrush mapping products that capture past changes in sagebrush quality (cover of sagebrush, forbs, and so forth) may explain variations in population trends.

\section{Products Completed in FY2016}

- Green, A.W., Aldridge, C.L., and O’Donnell, M.S., 2017, Investigating impacts of oil and gas development on greater sage-grouse: Journal of Wildlife Management, v. 81, no. 1, p. 46-57, https://doi.org/10.1002/jwmg.21179. [First published online in October 2016.]

- Monroe, A.P., Aldridge, C.L., Assal, T.J., Veblen, K.E., Pyke, D.A., and Casazza, M.L., 2017, Patterns in greater sage-grouse population dynamics correspond with public 
grazing records at broad scales: Ecological Applications, v. 27, no. 4, p. 1096-1107, https://doi.org/10.1002/eap.1512.

- In-progress article-J.A. Heinrichs, C.L. Aldridge, M.S. O’Donnell, and N.H. Schumaker, "Using dynamic population simulations to extend resource selection analyses and prioritize habitats for conservation.” (Published 2017: Heinrichs, J.A., Aldridge, C.L., O’Donnell, M.S., and Schumaker, N.H., 2017, Using dynamic population simulations to extend resource selection analyses and prioritize habitats for conservation: Ecological Modelling, v. 359, p. 449-459, https://doi.org/10.1016/j.ecolmodel.2017.05.017.)

- Monroe, A.P., Edmunds, D.R., and Aldridge, C.L., 2016, Effects of lek count protocols on greater sage-grouse population trend estimates: Journal of Wildlife Management, v. 80, p. 667-668, https://doi.org/10.1002/jwmg.1050.

- Completed statewide population viability analyses evaluating density dependent and independent models based on sage grouse lek trend data, summarized across various management units.

- Completed a statewide hierarchical clustering analysis to link leks into biologically related groups that can be used for hierarchical evaluation of sage grouse population trends in Wyoming. This approach is now being applied rangewide for greater sage grouse.

- Developed initial spatially explicit, individually based population viability analysis models for WLCI to evaluate the effects of future energy development and climate change on sage grouse populations.

Contact: Cameron L. Aldridge, 970-226-9433, aldridgec@usgs.gov 


\section{Mechanistic Understanding of Energy Resource Development Effects on Songbirds}

Three songbird species that nest almost exclusively within sagebrush habitats are found within the WLCI area-Brewer's sparrow (Spizella breweri), sagebrush sparrow (Artemisiospiza nevadensis), and sage thrasher (Oreoscoptes montanus). All three species are declining, at least in parts of their range, because of widespread habitat conversion and change. In collaboration with the Wyoming Game and Fish Department, we initiated this multiphase project to address the WLCI management need to identify the condition and distribution of sagebrush songbird habitats and key drivers of change.

In Phase I (2008-2009), we documented

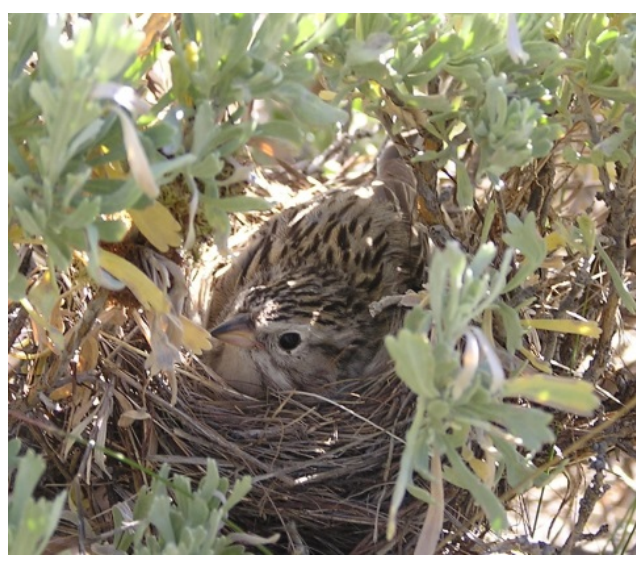

Brewer's sparrow incubating eggs. Photograph by Anna Chalfoun, U.S. Geological Survey. decreased nest survival of all three songbird species with natural gas well density in the Jonah and Pinedale Anticline Project Area. In Phase II (2011-2012), infrared video cameras confirmed that rodents were responsible for the vast majority of depredation events. In addition, abundance of deer mouse (Peromyscus maniculatus), thirteen-lined ground squirrel (Ictidomys tridecemlineatus), and Uinta ground squirrel (Urocitellus armatus) increased with surrounding habitat loss due to natural gas extraction, and nest survival of Brewer's and sagebrush sparrows was negatively associated with increased predator detections.

Collectively, our results suggest that natural gas development in western Wyoming alters the abundance of rodent nest predators, thereby increasing nest predation and decreasing nesting success. These results are concerning because nest success can directly affect population trends.

In FY2016, we continued Phase III, which included monitoring nests, identifying nest predator species, and assessing predator abundance to determine the spatial and temporal consistency of these relations. We also collected field data to test alternative hypotheses for why the abundance of rodent nest predators increases with natural gas development. Specifically, we tested whether lower abundance of the primary predators (raptors, canids, badgers) of rodents and (or) food augmentation could explain higher small mammal abundance. Raptors, canids, and badgers were slightly more abundant in areas with more natural gas extraction, thereby rejecting our first hypothesis. Tests of the food resource hypothesis are still underway.

Understanding the specific mechanisms underlying the effects of energy development on sagebrush songbirds will lead to more explicit management and mitigation recommendations for effectively maintaining songbird populations in the WLCI area and beyond, while also broadening our understanding of the Green River Basin ecosystem.

\section{Products Completed in FY2016}

- Presentations - “Is a Mesopredator Release Underlying Increased Songbird Nest Predation Rates Near Natural Gas Development?,” L.E. Sanders and A.D. ChalfounNorth American Ornithological Conference; Washington, D.C.; August 16-20, 2016Wyoming Chapter of The Wildlife Society and Society of Range Management Joint Conference; Cody, Wyo.; November 15-17, 2016. 
- In-progress article— “Mechanisms Underlying Nest Predation Near Natural Gas Development: A Test of the Mesopredator Release Hypothesis," L.E. Sanders and A.D. Chalfoun - in preparation for submission to "Journal of Applied Ecology."

Contacts: Anna D. Chalfoun, 307-766-6966, achalfou@uwyo.edu 


\section{Identifying Threshold Levels of Development that Impede Wyoming Mule Deer Migrations}

Increasingly, we understand that migration corridors are key habitats for migratory mule deer where they spend time foraging to regain energy stores along the route. As migration routes become constrained by development and human disturbance, a common response is for migrating animals to increase rate of movement, reduce stopover use, and occasionally detour around established routes. Thus, alterations to the behavior of animals during migration have the potential to modify their ability to track changing plant phenology across the landscape, also known as "surfing the green wave." By tracking the "green wave” from lower to higher elevations, mule deer prolong the period during which they can access the most nutritious foods of the year. They may spend days or even weeks at preferred stopover sites to feed before moving on. Protecting and ensuring access to these stopover sites is crucial to mule deer survival and population growth. Therefore, identifying migration routes and stopover areas can provide land managers with the information needed to plan energy developments in a manner that minimizes disruption of ungulate migration.

We used GPS movement data to evaluate the influence of development on the ability of mule deer to track phenology in southwestern Wyoming. We analyzed data collected from three study areas characterized by different development types: energy ( $n=163$ deer), residential $(n=121)$, and dispersed rural $(n=108)$. We sought to test whether development influenced greenwave surfing. To evaluate the ability of deer to track phenology, we calculated several metrics, including instantaneous rate of green-up (IRG; a phenology-based measure of forage quality) and days from peak green-up (DFP) for each animal for each year of available data. In general, across study areas and years, deer showed a strong tendency to surf the green wave, as evidenced by a correlation between the date a location was occupied by a deer and the date of peak IRG. We used regression analysis to evaluate whether intense development along a route reduced the ability of deer to optimally surf (fig. 7). This work helps to understand how development influences not only the behavior of animals, but also the functionality of the route and the foraging benefits migratory animals derive from surfing.

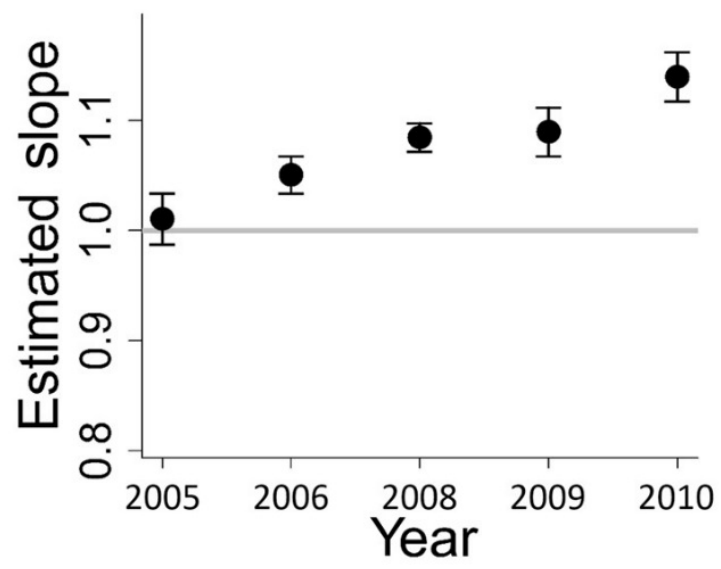

Figure 7. The estimated mean, with 95 percent confidence intervals (student t-test) of the slope of linear regression between the date of deer use at a given location and the date of peak instantaneous rate of green-up (IRG) at the same location for individual deer movements in each year in the energy study area. Confidence intervals overlapping 1.0 indicate that green-wave surfing was no different from perfect, while confidence intervals that do not overlap 1.0 indicate poor surfing ability. 


\section{Products Completed in FY2016}

- Presentation — “Evaluating the Influence of Development on Mule Deer Migration and Phenology Tracking,” T.B. Wyckoff, Hall Sawyer, M.J. Kauffman, and S.E. AlbekeWyoming Chapter of the Wildlife Society and Society of Range Management Joint Conference; Cody, Wyo.; November 15-17, 2016.

- Presentation- “Identifying Threshold Levels of Development That Impede Wyoming Ungulate Migrations,” T.B. Wyckoff-Annual Wyoming Cooperative Fish and Wildlife Unit Partners Meeting; Cheyenne, Wyo.; May 3, 2016.

- In-progress article_- "Evaluating the Influence of Development on Ungulate Migrations,” T.B. Wyckoff, M.J. Kauffman, S.E. Albeke, Hall Sawyer, and S.L. Garman-in preparation for submission to "Ecological Applications."

Contact: Matthew J. Kauffman, 307-766-5415, mkauffm1@uwyo.edu; Teal B. Wyckoff, wyckoff@uwyo.edu 


\section{Drivers of Native Fish Community Response to Oil and Gas Development}

\section{Previously titled “Influence of Energy Resource Development on Native Fish Communities.”}

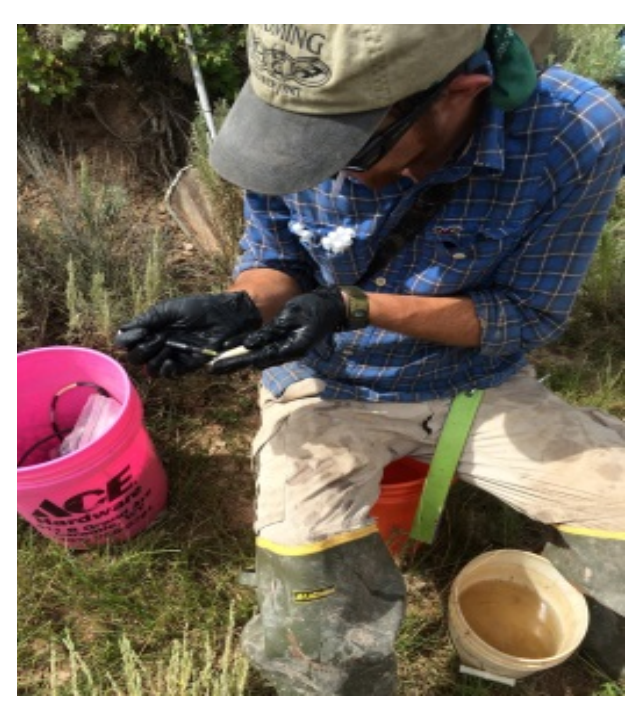

Richard Walker collecting blood sample from a mountain sucker. Photograph by Annika Walker, U.S. Geological Survey.

The rapid expansion of natural gas development in southwest Wyoming has raised concerns about its effects on key wildlife species and habitats. Our goals are (1) to evaluate potential mechanisms through which oil and gas development can affect fish and (2) to assess physiological and immunological effects of oil and gas development for fish. These goals correspond to two of WLCI's management needs: (1) identify condition and distribution of key wildlife species/habitats and species habitat requirements and (2) evaluate wildlife and livestock responses to development.

Our study examines the native fish community in southwestern Wyoming's streams whose presence indicates good water quality. We focus on three fish species in particular. The Colorado River cutthroat trout (Oncorhynchus clarki pleuriticus) is a Wyoming Species of Greatest Conservation Need and a highly valued sport fish that brings revenue to local economies. The mottled sculpin (Cottus bairdii) serves an important role as trout prey. The mountain sucker (Catostomus platyrhynchus) helps to clear algae from streambeds. Keeping this fish community intact supports the overall health of streams and entire watersheds. Our approach is a comparative study examining subwatersheds with differing levels of oil and gas development.

We have found that some of the native fish that live in southwestern Wyoming's coldwater streams are habitat specialists. Important habitat variables for fish included suspended sediment, cover from willow (Salix spp.), and water quality. The Colorado River cutthroat trout and mottled sculpin prefer cold, swiftly moving streams with rocky or gravelly streambeds. High-quality coldwater fish habitat is free of sediments and salts and has ample willow cover to shade the water, thereby keeping the water cool and moderating swings in water temperatures. At the habitat scale, resource managers can use this new information to target sites for reducing sediment loads, restoring stream vegetation cover, and preventing petroleum spills. At the landscape scale, the information gained through this work will help resource managers determine appropriate development levels for a given watershed so that habitat and stream function are maintained. The information also helps to point out priority areas in need of monitoring and protection measures. Finally, the absence of native coldwater fish in any one stream or drainage can alert resource managers that stream habitat and water quality may be in decline.

Our initial work focused primarily on habitat, so in FY2016, we expanded the study to focus on two other important potential mechanistic pathways by which oil and gas development can affect fish: hydrology and resource availability. We are working with Cheryl A. Eddy-Miller (USGS Wyoming-Montana Water Science Center) on an extensive hydrologic characterization of the study streams and collecting resource availability data for all study sites. In addition, we have expanded our fish sampling to measure physiological and immunological responses for two species: mountain sucker and mottled sculpin. In FY2016, we also collected our fifth year of fish community data (led by Richard Walker, Ph.D. student, University of Wyoming). 


\section{Products Completed in FY2016}

- In-progress article_— “Differential vulnerability of fish to energy development,” C.E. Girard and A.W. Walters-in preparation for submission to peer-reviewed scientific journal.

- Five presentations at scientific conferences:

- Presentations - “The Role of Context Dependency in Understanding the Effects of Low Flow Events on Fish,” Annika Walters-American Fisheries Society annual meeting; Kansas City, Mo.; August 21-25, 2016—Society for Freshwater Science annual meeting; Sacramento, Calif.; May 21-26, 2016.

- Plenary talk — “Implications of Oil and Natural Gas Development for Native Fish Populations,” Annika Walters-Rocky Mountain Society for Environmental Toxicology and Chemistry; Fort Collins, Colo.; 2016.

- Presentations - “Does Oil and Natural Gas Development and Hydrology Interact to Affect Fish Populations,” Richard Walker, Caitlin Girard, and Annika WaltersSociety for Freshwater Science annual meeting; Sacramento, Calif.; May 21-26, 2016 - Colorado/Wyoming American Fisheries Society meeting [award for best student paper]; Laramie, Wyo.; 2016.

Contact: Annika W. Walters, 307-766-5473, annika.walters@uwyo.edu 


\section{Project Reports-Data and Information Management}

\section{Data Management Framework and Catalog}

This project addresses the need to access, manage, and analyze WLCI data and information resources by providing online tools for (1) cataloging and archiving data and information, (2) discovering and using these resources, and (3) making the resources available to WLCI researchers, decision makers and the public through the WLCI website. The WLCI Data Catalog developed and hosted by the USGS is available at https://www.wlci.gov/tools-andresources. It describes and provides access to datasets and project information associated with the WLCI.

In FY2016, the Information Management Team supported updates and maintenance of the WLCI Data Catalog and website. We added updates of newly published data from USGS scientists into the interactive map application on the WLCI website, finalizing efforts started in FY2015. We also supported data documentation and release for various WLCI products (such as the WLCI Important Agricultural Lands Assessment Project, https://doi.org/10.5066/F7ZC80X7).

The Information Management Team maintained security and functionality of the WLCI website. To help provide feedback to the WLCI community, we incorporated Google Analytics into the website. In addition, we implemented updates to display newly relevant files, links, photos, and information provided by the WLCI team.

\section{Products Completed in FY2016}

- Presentations at the USGS Science Meeting provided guidance on WLCI data release, data management, and data visualization. USGS tools and resources were described to help WLCI scientists meet new USGS policies described in the USGS Instructional Memorandum IM OSQI 2015-03, "Review and Approval of Scientific Data for Release” (replaced by SM 502.8, January 13, 2017, https:/www2.usgs.gov/usgs-manual/500/5028.html/). A presentation on the 2015 National Fish Habitat Partnership web report (Crawford and others, 2016) provided examples of how documenting and delivering data using a standard approach can allow for efficient and interactive visualizations of information. Through this presentation and interaction with the WLCI Science Team, the Information Management Team suggested approaches to improve organization and documentation of information including key topics for organization of information.

Contact: Daniel Wieferich, 303-202-4594, dwieferich@usgs.gov 


\section{References Cited and FY2016 WLCI Publications}

Aikens, E.O., Kauffman, M.J., Merkle, J.A., Dwinnell, S.P.H., Gralick, G.L., and Monteith, K.L., 2017, The greenscape shapes surfing of resource waves in a large migratory herbivore: Ecology Letters, v. 20, p. 741-750, accessed January 29, 2018, at https://doi.org/10.1111/ele.12772.

Assal, T.J., Anderson, P.J., and Sibold, Jason, 2016, Spatial and temporal trends of drought effects in a heterogeneous semi-arid forest ecosystem: Forest Ecology and Management, v. 365, p. 137-151, accessed January 29, 2018, at https://doi.org/10.1016/j.foreco.2016.01.017.

AWS Truepower, LLC, 2010, Wyoming 80-meter wind resource map: AWS Truepower, LLC, accessed February 16, 2018, at https://windexchange.energy.gov/states/wy.

Biewick, L.R.H., and Jones, N.R., 2012, Energy map of southwestern Wyoming, Part A-Coal and wind: U.S. Geological Survey Data Series 683, 18 p., accessed January 29, 2018, at https://pubs.usgs.gov/ds/683/.

Bowen, Z.H., Aldridge, C.L., Anderson, P.J., Assal, T.J., Baer, L.A., Bristol, Sky, Carr, N.B., Chong, G.W., Diffendorfer, J.E., Fedy, B.C., Garman, S.L., Germaine, Stephen, Grauch, R.I., Homer, Collin, Manier, Daniel, Kauffman, M.J., Latysh, Natalie, Melcher, C.P., Miller, K.A., Montag, Jessica, Nutt, C.J., Potter, Christopher, Sawyer, Hall, Smith, D.B., Sweat, M.J., and Wilson, A.B., 2009a, U.S. Geological Survey science for the Wyoming Landscape Conservation Initiative_-2008 annual report: U.S. Geological Survey Open-File Report 20091201, 83 p., accessed January 29, 2018, at https://pubs.usgs.gov/of/2009/1201/.

Bowen, Z.H., Aldridge, C.L., Anderson, P.J., Assal, T.J., Bartos, T.T., Biewick, L.R., Boughton, G.K., Chalfoun, A.D., Chong, G.W., Dematatis, M.K., Eddy-Miller, C.A., Garman, S.L., Germaine, S.S., Homer, C.G., Huber, Christopher, Kauffman, M.J., Latysh, Natalie, Manier, Daniel, Melcher, C.P., Miller, A.R., Miller, K.A., Olexa, E.M., Schell, Spencer, Walters, A.W., Wilson, A.B., and Wyckoff, T.B., 2015, U.S. Geological Survey science for the Wyoming Landscape Conservation Initiative-2014 annual report: U.S. Geological Survey Open-File Report 2015-1091, 61 p., accessed January 29, 2018, at https://pubs.usgs.gov/of/2015/1091/.

Bowen, Z.H., Aldridge, C.L., Anderson, P.J., Assal, T.J., Bartos, T.T., Chalfoun, A.D., Chong, G.W., Dematatis, M.K., Eddy-Miller, C.A., Garman, S.L., Germaine, S.S., Homer, C.G., Huber, C.C., Kauffman, M.J., Manier, D.J., Melcher, C.P., Miller, K.A., Norkin, Tamar, Sanders, L.E., Walters, A.W., Wilson, A.B., and Wyckoff, T.B., 2016, U.S. Geological Survey science for the Wyoming Landscape Conservation Initiative-2015 annual report: U.S. Geological Survey Open-File Report 2016-1141, 59 p., accessed January 29, 2018, at https://doi.org/10.3133/ofr20161141.

Bowen, Z.H., Aldridge, C.L., Anderson, P.J., Assal, T.J., Bern, C.R., Biewick, L.R.H., Boughton, G.K., Carr, N.B., Chalfoun, A.D., Chong, G.W., Clark, M.L., Fedy, B.C., Foster, Katharine, Garman, S.L., Germaine, Stephen, Hethcoat, M.G., Homer, Collin, Kauffman, M.J., Keinath, Douglas, Latysh, Natalie, Manier, Daniel, McDougal, R.R., Melcher, C.P., Miller, K.A., Montag, Jessica, Potter, C.J., Schell, Spencer, Shafer, S.L., Smith, D.B., Sweat, M.J., and Wilson, A.B., 2014a, U.S. Geological Survey science for the Wyoming Landscape Conservation Initiative-2012 annual report: U.S. Geological Survey Open-File Report 20141093, 71 p., accessed January 29, 2018, at https://pubs.usgs.gov/of/2014/1093/.

Bowen, Z.H., Aldridge, C.L., Anderson, P.J., Assal, T.J., Bern, C.R., Biewick, L.R.H., Boughton, G.K., Carr, N.B., Chalfoun, A.D., Chong, G.W., Dematatis, Marie, Fedy, B.C., Garman, S.L., Germaine, Stephen, Hethcoat, M.G., Homer, Collin, Huber, Christopher, 
Kauffman, M.J., Latysh, Natalie, Manier, Daniel, Melcher, C.P., Miller, K.A., Potter, C.J., Schell, S.L., Smith, D.B., Sweat, M.J., Walters, Annika, and Wilson, A.B., 2014b, U.S. Geological Survey science for the Wyoming Landscape Conservation Initiative-2013 annual report: U.S. Geological Survey Open-File Report 2014-1213, 60 p., accessed January 29, 2018, at https://pubs.usgs.gov/of/2014/1213/.

Bowen, Z.H., Aldridge, C.L., Anderson, P.J., Assal, T.J., Biewick, L.R.H., Blecker, S.W., Boughton, G.K., Bristol, Sky, Carr, N.B., Chalfoun, A.D., Chong, G.W., Clark, M.L., Diffendorfer, J.E., Fedy, B.C., Foster, Katharine, Garman, S.L., Germaine, Stephen, Hethcoat, M.G., Holloway, Joann, Homer, Collin, Kauffman, M.J., Keinath, Douglas, Latysh, Natalie, Manier, Daniel, McDougal, R.R., Melcher, C.P., Miller, K.A., Montag, Jessica, Olexa, E.M., Potter, C.J., Schell, Spencer, Shafer, S.L., Smith, D.B., Stillings, L.L., Sweat, M.J., Tuttle, Michele, and Wilson, A.B., 2013, U.S. Geological Survey science for the Wyoming Landscape Conservation Initiative-2011 annual report: U.S. Geological Survey Open-File Report 20131033, 145 p., accessed January 29, 2018, at https://pubs.usgs.gov/of/2013/1033/.

Bowen, Z.H., Aldridge, C.L., Anderson, P.J., Assal, T.J., Biewick, L.R.H., Blecker, S.W., Boughton, G.K., Bristol, Sky, Carr, N.B., Chalfoun, A.D., Chong, G.W., Clark, M.L., Diffendorfer, J.E., Fedy, B.C., Foster, Katharine, Garman, S.L., Germaine, Stephen, Holloway, JoAnn, Homer, Collin, Kauffman, M.J., Keinath, Douglas, Latysh, Natalie, Manier, Daniel, McDougal, R.R., Melcher, C.P., Miller, K.A., Montag, Jessica, Potter, C.J., Schell, Spencer, Shafer, S.L., Smith, D.B., Stillings, L.L., Tuttle, Michele, and Wilson, A.B., 2011, U.S. Geological Survey science for the Wyoming Landscape Conservation Initiative-2010 annual report: U.S. Geological Survey Open-File Report 2011-1219, 146 p., accessed January 29, 2018, at https://pubs.usgs.gov/of/2011/1219/.

Bowen, Z.H., Aldridge, C.L., Anderson, P.J., Assal, T.J., Biewick, L.R.H., Blecker, S.W., Bristol, Sky, Carr, N.B., Chalfoun, A.D., Chong, G.W., Diffendorfer, J.E., Fedy, B.C., Garman, S.L., Germaine, Stephen, Grauch, R.I., Holloway, JoAnn, Homer, Collin, Kauffman, M.J., Keinath, Douglas, Latysh, Natalie, Manier, Daniel, McDougal, R.R., Melcher, C.P., Miller, K.A., Montag, Jessica, Nutt, C.J., Potter, C.J., Sawyer, Hall, Schell, Spencer, Shafer, S.L., Smith, D.B., Stillings, L.L., Tuttle, Michele, and Wilson, A.B., 2010, U.S. Geological Survey science for the Wyoming Landscape Conservation Initiative-2009 annual report: U.S. Geological Survey Open-File Report 2010-1231, 106 p., accessed January 29, 2018, at https://pubs.usgs.gov/of/2010/1231/.

Bowen, Z.H., Aldridge, C.L., Anderson, P.J., Chong, G.W., Drummond, M.A., Homer, Collin, Johnson, R.C., Kauffman, M.J., Knick, S.T., Kosovich, J.J., Miller, K.A., Owens, Tom, Shafer, S., and Sweat, M.J., 2009b, U.S. Geological Survey science strategy for the Wyoming Landscape Conservation Initiative: U.S. Geological Survey Scientific Investigations Report 2008-5195, 26 p., accessed January 29, 2018, at http://pubs.usgs.gov/sir/2008/5195/.

Brown, J.F., Howard, Daniel, Wylie, Bruce, Frieze, Aaron, Ji, Lei, and Gacke, Carolyn, 2015, Application-ready expedited MODIS data for operational land surface monitoring of vegetation condition: Remote Sensing, v. 7, p. 16226-16240, accessed January 29, 2018, at https://doi.org/10.3390/rs71215825.

Chong, Geneva, Miller, Brian, Morisette, Jeffrey, Steltzer, Heidi, Bern, Carleton, Talbert, Marian, Talbert, Colin, and Shory, Rick, 2015, Use of PhenoCam data in a multi-scale evaluation of Wyoming sagebrush phenology [abs.], in Integrating research and management of change from the mountains to the plains-2015 Open Science Conference, Fort Collins, 
Colo., May 20-22, 2015, Proceedings: North Central Climate Science Center, Colorado State University, accessed January 29, 2018, at http://nccsc.colostate.edu/conference/program.

Clause, K.J., and Randall, Jill, 2014, Sagebrush die-off report: Pinedale, Wyo., Natural

Resources Conservation Service and Wyoming Game and Fish Department, 57 p.

Crawford, Steve, Whelan, Gary, Infante, D.M., Blackhart, Kristan, Daniel, W.M., Fuller, P.L., Birdsong, Tim, Wieferich, D.J., McClees-Funinan, Ricardo; Stedman, S.M., Herreman, Kyle, and Ruhl, Peter, 2016, Through a fish's eye-The status of fish habitats in the United States 2015: National Fish Habitat Partnership, variously paged, accessed January 29, 2018, at http://assessment.fishhabitat.org/.

Damm, Phillip, and Randall, Jill, 2012, Wyoming Range mule deer habitat management planBig Piney-LaBarge area: Pinedale, Wyo., Wyoming Game and Fish Department, Pinedale Regional Office, 71 p., accessed January 29, 2018, at https://wgfd.wyo.gov/Habitat/StatewideMule-Deer-Initiatives/Mule-Deer-Public-Working-Groups/The-Wyoming-Range.

D’Erchia, Frank, ed., 2008, Wyoming Landscape Conservation Initiative Science Workshop proceedings, May 15-17, 2007: U.S. Geological Survey Scientific Investigations Report 2008-5073, 96 p, accessed January 29, 2018, at https:/pubs.usgs.gov/sir/2008/5073/.

D’Erchia, Frank, 2016, Wyoming Landscape Conservation Initiative-A case study in partnership development: U.S. Geological Survey Circular 1423, 17 p., accessed January 29, 2018, at https://doi.org/10.3133/cir1423.

Green, A.W., Aldridge, C.L., and O’Donnell, M.S., 2017, Investigating impacts of oil and gas development on greater sage-grouse: Journal of Wildlife Management, v. 81, no. 1, p. 46-57, accessed January 29, 2018, at https://doi.org/10.1002/jwmg.21179.

Kenney, T.A., 2010, Levels at gaging stations: U.S. Geological Survey Techniques and Methods, book 3, chap. A19, 60 p., accessed January 29, 2018, at https://pubs.usgs.gov/tm/tm3A19/.

Monroe, A.P., Aldridge, C.L., Assal, T.J., Veblen, K.E., Pyke, D.A., and Casazza, M.L., 2017, Patterns in greater sage-grouse population dynamics correspond with public grazing records at broad scales: Ecological Applications, v. 27, no. 4, p. 1096-1107, accessed January 29, 2018, at https://doi.org/10.1002/eap.1512.

Monroe, A.P., Edmunds, D.R., and Aldridge, C.L., 2016, Effects of lek count timing on greater sage-grouse population trend estimates: Journal of Wildlife Management, v. 4, p. 667-668, accessed January 29, 2018, at https://doi.org/10.1002/jwmg.1050.

Nelson, Z.J., Weisberg, P.J., and Kitchen, S.G., 2014, Influence of climate and environment on post-fire recovery of mountain big sagebrush: International Journal of Wildland Fire, v. 23, no. 1, p. 131-142, accessed January 29, 2018, at https://doi.org/10.1071/WF13012.

Sauer, V.B., and Turnipseed, D.P., 2010, Stage measurement at gaging stations: U.S. Geological Survey Techniques and Methods, book 3, chap. A7, 45 p., accessed January 29, 2018, at http://pubs.usgs.gov/tm/tm3-a7/.

Turnipseed, D.P., and Sauer, V.B., 2010, Discharge measurements at gaging stations: U.S. Geological Survey Techniques and Methods, book 3, chap. A8, 87 p., accessed January 29, 2018, at http://pubs.usgs.gov/tm/tm3-a8/.

U.S. Geological Survey, variously dated, National field manual for the collection of waterquality data: U.S. Geological Survey Techniques of Water-Resources Investigations, book 9, chaps. A1-A9, variously paged, accessed January 29, 2018, at http://pubs.water.usgs.gov/twri9A.

Wagner, R.J., Boulger, R.W., Jr., Oblinger, C.J., and Smith, B.A., 2006, Guidelines and standard procedures for continuous water-quality monitors - Station operation, record computation, and 
data reporting: U.S. Geological Survey Techniques and Methods, book 1, chap. D3, 51 p. and 8 attachments, accessed January 29, 2018, at http://pubs.water.usgs.gov/tm1d3.

Wheeler, J.D., and Eddy-Miller, C.A., 2005, Seepage investigation on selected reaches of Fish Creek, Teton County, Wyoming, 2004: U.S. Geological Survey Scientific Investigations Report 2005-5133, 20 p., accessed January 29, 2018, at http://pubs.usgs.gov/sir/2005/5133/. Wilson, A.B., Hayes, T.S., Benson, M.E., Yager, D.B., Anderson, E.D., Bleiwas, D.I., DeAngelo, Jacob, Dicken, C.L., Drake, R.M., II, Fernette, G.L., Giles, S.A., Glen, J.M.G., Haacke, J.E., Horton, J.D., Parks, H.L., Rockwell, B.W., and Williams, C.F., 2016, Geology and mineral resources of the Southwestern and South-Central Wyoming Sagebrush Focal Area, Wyoming, and the Bear River Watershed Sagebrush Focal Area, Wyoming and Utah, chap. E of Day, W.C., Frost, T.P., Hammarstrom, J.M., and Zientek, M.L., eds., Mineral resources of the Sagebrush Focal Areas of Idaho, Montana, Nevada, Oregon, Utah, and Wyoming: U.S. Geological Survey Scientific Investigations Report 2016-5089-E, 128 p., accessed January 29, 2018, at https://pubs.er.usgs.gov/publication/sir20165089E.

Wyoming Game and Fish Department, 2010, State Wildlife Action Plan: Cheyenne, Wyo., Wyoming Game and Fish Department, variously paged [910 p.], accessed January 29, 2018, at https://wgfd.wyo.gov/Habitat/Habitat-Plans/Wyoming-State-Wildlife-Action-Plan. 


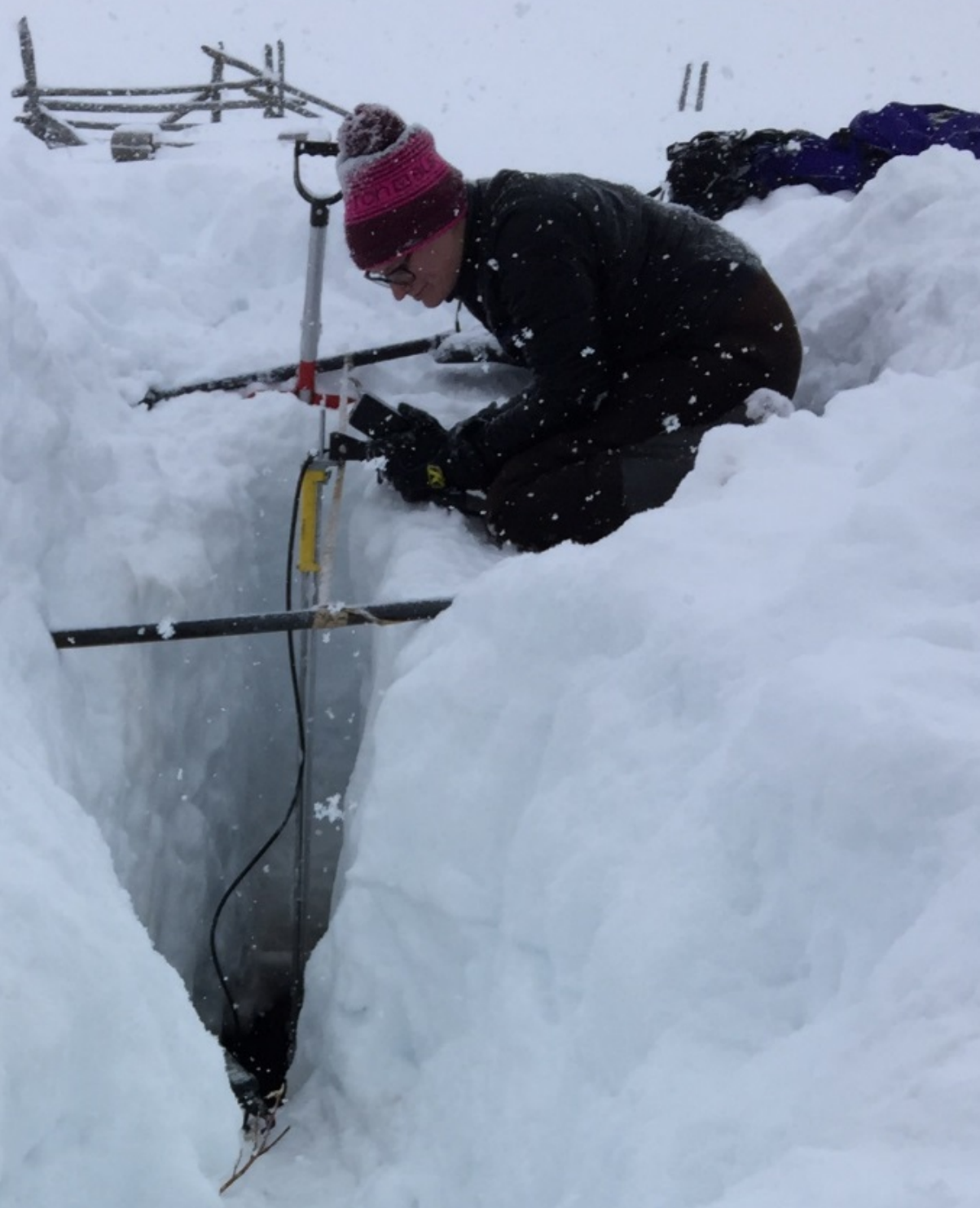

ISSN 2331-1258 (online)

https://doi.org/10.3133/ofr20181048 